\title{
Evaluation of orthodontically induced external root resorption following orthodontic treatment using cone beam computed tomography (CBCT): a systematic review and meta-analysis
}

\author{
Samandara, Aikaterini ; Papageorgiou, Spyridon N ; Ioannidou-Marathiotou, Ioulia ; Kavvadia-Tsatala, \\ Smaragda ; Papadopoulos, Moschos A
}

\begin{abstract}
Background: Orthodontically induced external root resorption (OIRR) is a pathologic consequence of orthodontic tooth movement. However, the limitations of two-dimensional radiography suggest that cone beam computed tomography (CBCT) with its three-dimensional capabilities might be more suitable to assess OIRR. Objective: The aim of this study was to assess in an evidence-based manner data on linear or volumetric OIRR measurements of permanent teeth by means of CBCT, during and/or after the end of orthodontic treatment. Search methods: Unrestricted electronic and hand searches were performed up to January 2017 in 15 databases. Selection criteria methods: Randomized clinical trials, prospective, and retrospective non-randomized studies assessing OIRR during and/or after orthodontic treatment using CBCT in human patients were included. Data collection and analysis: After duplicate study selection, data extraction, and risk-of-bias assessment according to the Cochrane guidelines, random-effects meta-analyses, followed by subgroup, meta-regression, and sensitivity analyses were also performed in order to evaluate factors that affect OIRR. Results: A total of 33 studies (30 datasets) were included in the qualitative analysis while data from 27 of them were included in the quantitative analysis. Direct comparisons from randomized trials found little to no influence of appliance-related factors on OIRR. Explorative analyses including non-randomized studies found a pooled OIRR of $0.79 \mathrm{~mm}$ based on all included studies and $0.86 \mathrm{~mm}$ when OIRR was assessed at the end of orthodontic treatment. Statistically significant differences in OIRR were found according to tooth type or jaw, inclusion of extractions, treatment duration, and diagnostic accuracy of the CBCT. Conclusions: Based on the results of this study, CBCT seems to be a reliable tool to examine OIRR during or at the end of orthodontic treatment. Although the average OIRR measured with CBCT seems to lack clinical relevance, there are certain factors that may affect OIRR following orthodontic treatment. Nevertheless, due to data heterogeneity and low quality of the included studies, the corresponding results should be interpreted with some caution.
\end{abstract}

DOI: https://doi.org/10.1093/ejo/cjy027

Posted at the Zurich Open Repository and Archive, University of Zurich

ZORA URL: https://doi.org/10.5167/uzh-186071

Journal Article

Accepted Version

Originally published at:

Samandara, Aikaterini; Papageorgiou, Spyridon N; Ioannidou-Marathiotou, Ioulia; Kavvadia-Tsatala, Smaragda; Papadopoulos, Moschos A (2019). Evaluation of orthodontically induced external root resorption following orthodontic treatment using cone beam computed tomography (CBCT): a systematic review and meta-analysis. European Journal of Orthodontics, 41(1):67-79. 
DOI: https://doi.org/10.1093/ejo/cjy027 


\section{TITLE PAGE}

Evaluation of orthodontically induced external root resorption following orthodontic treatment using Cone Beam Computed Tomography (CBCT): a systematic review and meta-analysis

Katerina Samandara ${ }^{1}$, Spyridon N. Papageorgiou ${ }^{2}$, loulia loannidou-Marathiotou ${ }^{1}$, Smaragda KavvadiaTsatala ${ }^{1}$, Moschos A. Papadopoulos ${ }^{1}$

${ }^{1}$ Department of Orthodontics, Faculty of Dentistry, Aristotle University of Thessaloniki, Thessaloniki, Greece

${ }^{2}$ Clinic of Orthodontics and Pediatric Dentistry, Center of Dental Medicine, University of Zurich, Zurich, Switzerland

Running title: CBCT for orthodontic root resorption

Correspondence to: Moschos A. Papadopoulos, Department of Orthodontics, School of Health Sciences, Faculty of Dentistry, Aristotle University of Thessaloniki, GR-54124 Thessaloniki, Greece. E-mail: mikepap@dent.auth.gr.

Words in abstract: $315 / 330$

Words in text: $4611 / 5000$

Keywords: orthodontics, adverse effects, root resorption, clinical trials; systematic review, meta-analysis

Conflicts of interest: none. 


\section{Summary}

Background: Orthodontically induced external root resorption (OIRR) is a pathologic consequence of orthodontic tooth movement. However, the limitations of two-dimensional radiography suggest that cone beam computed tomography (CBCT) with its three-dimensional capabilities might be more suitable to assess OIRR.

Objective: The aim of this study was to assess in an evidence-based manner data on linear or volumetric OIRR measurements of permanent teeth by means of CBCT, during and/or after the end of orthodontic treatment.

Search methods: Unrestricted electronic and hand searches were performed up to January 2017 in 15 databases.

Selection criteria methods: Randomized clinical trials, prospective and retrospective non-randomized studies assessing OIRR during and/or after orthodontic treatment using CBCT in human patients were included.

Data collection and analysis: After duplicate study selection, data extraction, and risk-of-bias assessment according to the Cochrane guidelines, random-effects meta-analyses, followed by subgroup, meta-regression, and sensitivity analyses were also performed in order to evaluate factors that affect OIRR.

Results: A total of 33 studies (30 datasets) were included in the qualitative analysis while data from 27 of them were included in the quantitative analysis. Direct comparisons from randomized trials found little to no influence of appliance-related factors on OIRR. Explorative analyses including non-randomized studies found pooled OIRR was $0.79 \mathrm{~mm}$ based on all included studies and $0.86 \mathrm{~mm}$ when OIRR was assessed at the end of orthodontic treatment. Statistically significant differences in OIRR were found according to tooth type or jaw, inclusion of extractions, treatment duration, and diagnostic accuracy of the CBCT.

Conclusions: Based on the results of this study, CBCT seems to be a reliable tool to examine OIRR during or at the end of orthodontic treatment. Although the average OIRR measured with CBCT seems to lack clinical relevance, there are certain factors that may affect OIRR following orthodontic treatment. 
Nevertheless, due to data heterogeneity and low quality of the included studies, the corresponding results should be interpreted with some caution.

Registration: PROSPERO (CRD42016030131)

Funding: None. 


\section{BLINDED MANUSCRIPT}

\section{Introduction}

\section{Rationale}

Orthodontically induced root resorption (OIRR) is a frequent complication of orthodontic tooth movement with complex aetiology and several patient- or treatment-related risk factors being suggested as relevant (1). Proposed patient-related factors include genetics (2), gender (3), age (4), tooth type (5), systemic factors (6), root morphology (7), and history of trauma or previous root resorption (8). On the other hand, proposed treatment-related factors include appliances type (9), treatment duration (10), type of tooth movement (11), applied force magnitude (12), duration of force application (13), and extraction treatment (14).

Diagnosis of OIRR is done in most cases radiographically, since clinical symptoms are for the most part absent and increased tooth mobility is seen only in severe cases with additional alveolar bone loss through time (15). Usually, two-dimensional radiographic (2D) methods like periapical or panoramic radiographs are taken before, during, and after orthodontic treatment to monitor OIRR (16). Studies using 2D imaging techniques found OIRR to be less than $0.60 \mathrm{~mm}$ at the end of treatment with the maxillary incisors being more frequently and severely affected $(5,10,17)$. However, OIRR affects every aspect of the root surface in all three-dimensions and therefore, 2D might mask the true amount of OIRR. Additionally, the true extent of OIRR might be misestimated due to magnification errors and problematic repeatability of 2D radiographs (18).

Cone Beam Computed Tomography (CBCT) was introduced as a three-dimensional diagnostic modality capable of imaging complex dental and maxillofacial structures and quickly adopted in dentistry due to its reduced radiation dose compared to conventional computed tomography (19). On the other side, considerable variation in CBCT radiation doses exists according to the exposure protocol and there might be as much as 15 -fold difference between a low-dose and a high-resolution protocol with the same field of view (19). The diagnostic value of CBCT in the diagnosis of OIRR lies on its ability to obtain distortion-free and reproducible images of the roots (20) with high sensitivity and specificity (21). Additionally, three-dimensional reconstruction of 2D CBCT slices enables accurate quantification of both linear and volumetric OIRR measurements (22) and compensates for changes in root position or angulation during orthodontic treatment (23).

\section{Objectives}


In light of the considerable differences between the two imaging modalities and potential advantages of threedimensional imaging with $\mathrm{CBCT}$ in quantifying OIRR, the present systematic review sought to summarize evidence from existing clinical studies assessing linear or volumetric OIRR with CBCT in order to primarily quantify the average OIRR that can be expected after orthodontic treatment. The secondary aim was to identify significant patient-, treatment-, or imaging-related factors that are significantly associated with OIRR.

\section{Materials and methods}

\section{Protocol and registration}

The protocol for the present systematic review was developed a priori according to the Cochrane Handbook for Systematic Reviews of Interventions 5.1.0 (24) and registered in PROSPERO (CRD42016030131). The present systematic review is conducted according to the guidelines of the Cochrane Handbook for Systematic Reviews of Interventions version 5.1.0 (24) and is reported according to the Preferred Reporting Items for Systematic Reviews and Meta-Analyses (PRISMA) statement (25).

\section{Information sources and literature search}

A total of fifteen databases were systematically searched from their inception up to July 2015 for published, ongoing, or unpublished studies without any limitation regarding language, publication year, or publication status (Supplementary Table 1). Electronic searches were updated in January 2017, while the reference and citation lists of all included studies and identified relevant systematic reviews were manually searched for eligible studies.

\section{Eligibility criteria}

Eligibility criteria were determined a priori according to the PICOS (Participant-Intervention-ComparisonOutcome-Study design) schema (Supplementary Table 2). As a result, randomized clinical trials and prospective or retrospective non-randomized clinical studies assessing linear or volumetric OIRR with CBCT in patients in the permanent dentition with fully developed tooth roots examined during and/or after orthodontic treatment were included. Studies with untreated control groups were initially not expected to be found, since it is unethical to expose patients to radiation without proper indications and when no orthodontic intervention has been performed, 
but were nevertheless included, if available. All other clinical or non-clinical study designs not fulfilling the criteria were excluded.

\section{Study selection}

The titles/abstracts of identified studies were screened by one author (AS), while an independent checking of their full texts for eligibility was performed by another author (SNP), and conflicts were resolved by a third author (MAP).

\section{Data collection}

Data extraction was performed independently by two authors (AS, SNP) using pre-determined and piloted extraction forms covering study design, clinical setting, country, patient characteristics, number/ age/ sex of patients, applied orthodontic intervention, treatment duration, teeth assessed for OIRR, outcome assessed, timing of outcome measurement, CBCT technical characteristics, and potential conflict of interests. Discrepancies in data extraction between the two authors were likewise resolved by a third author (MAP), while authors of included trials were contacted for missing or unclear information.

\section{Risk of bias in individual trials}

The Cochrane Collaboration's Risk of Bias Tool was used to assess the risk of bias in randomized clinical trials (24), while a modified version of the Downs and Black checklist (26) was used to assess the risk of bias of nonrandomized studies. Risk of bias was assessed independently by two authors (AS, SNP) and potential conflicts between them were resolved by the third author (MAP).

\section{Data synthesis}

The primary outcome of this systematic review was the amount of OIRR in patients treated with fixed appliances. This was measured either as change in length or volume and either after an initial phase of treatment or after the end of treatment, but was assessed separately. The secondary outcome was the amount of OIRR after conventional rapid maxillary expansion (RME), surgically-assisted RME, functional appliance treatment, or any other kind of appliance. For both the primary and all secondary outcomes the average amount of OIRR, as well as the influence of 
any patient-, tooth-, treatment-, or outcome-related factors was investigated, including among others patient age, sex, tooth type, treatment duration, inclusion of extractions, voxel size, and OIRR measurement unit.

Data were summarized and considered suitable for pooling if the corresponding studies used similar interventions in the same way and reported similar outcomes. The amount of OIRR in terms of alterations in the root length or volume measured by CBCTs was calculated as initial length/volume minus final length/volume, so that positive values indicated root resorption and negative values indicated root elongation. From each included study data from all available study arms pertaining to different teeth/roots, appliances, or follow-up were extracted.

Since OIRR as response to treatment was expected to vary according to population variations, genetic predisposition, differences in the applied treatment mechanics, and differences in CBCT protocol, a random-effects model was deemed appropriate to calculate the mean across distributions of true OIRR effects (27). For the main analysis all study arms of each study were pooled together (24) and the novel Paule-Mandel random-effects estimator was used over the DerSimonian-Laird one, since it outperforms the latter (28). For the main analysis the mean difference (MD) in OIRR was used to quantify differences between groups. In explorative meta-analyses where multiple study arms from a study were included, a robust variance estimation of random-effects using the DerSimonian-Laird method was performed to account for clustering of study arms within studies (29). In the explorative analyses the average OIRR within- and across-groups was quantified.

The extent and impact of heterogeneity across studies was assessed by forest plot inspection and formally quantified using the tau ${ }^{2}$ and $\mathrm{I}^{2}$ metrics, respectively (24). The following arbitrary categories for $\mathrm{I}^{2}$ were adopted (24): $I^{2}=0-40 \%$ : non-important inconsistency; $I^{2}=30-60 \%$ : moderate inconsistency; $I^{2}=50-90 \%$ : substantial inconsistency; and $\mathrm{I}^{2}>75-100 \%$ : considerable inconsistency.

All analyses were performed on Stata SE 14.0 (StataCorp, College Station, TX) by one author (SNP) with an open dataset in Zenodo (30). The level of significance was set to a two-sided $\mathrm{P}<0.05$ except for tests of within- or between-subgroups heterogeneity, where it was set at $\mathrm{P}<0.10$ (24).

\section{Risk of bias across studies and additional analyses}

Potential sources of heterogeneity attributed to patient-, tooth-, treatment-, or outcome-related factors were assessed with the use of pre-specified mixed-effects subgroup and meta-regression analyses with at least 5 studies. Investigated factors included patient age, sex, tooth type, treatment phase (initial or complete treatment), treatment 
duration, and inclusion of extractions. Indications of reporting biases (including small-study effects and publication bias) were assessed with Egger's linear regression test (31) and contour-enhanced funnel plots, should ten or more trials be pooled in a meta-analysis.

The overall quality of evidence (confidence in effect estimates) for each outcome was rated using the Grading of Recommendations Assessment, Development and Evaluation (GRADE) approach (32). The cut-offs of minimal clinical important, large, and very large effects for linear OIRR were arbitrarily defined a priori as 0.75 $\mathrm{mm}, 1.50 \mathrm{~mm}, 3.00 \mathrm{~mm}$ (or $10.0 \mathrm{~mm}^{3}, 20.0 \mathrm{~mm}^{3}$, and $40.0 \mathrm{~mm}^{3}$ for volumetric OIRR) and used to augment the produced forest plots with contours of effect magnitude (33).

Robustness of the results was checked with sensitivity analyses according to the following study design and outcome measurement method factors: randomized or non-randomized studies, prospective or retrospective studies, OIRR measurement at the tooth or root level, and diagnostic accuracy (based on a study (34) finding differences in measured OIRR using a cut-off voxel size of $0.2 \mathrm{~mm}$ ).

\section{Results}

\section{Study selection}

The electronic and manual literature searches yielded 3442 records that were reduced to 2206 records after the removal of duplicates. A total of 2162 records were excluded on the basis of title, abstract, and full text according to the specific inclusion and exclusion criteria (Supplementary Tables 3a-3c). The full text of six publications couldn't be retrieved, even after author communication attempts via email (Supplementary Table 4). Consequently, 33 publications were included in the study, which after collating multiple publications pertaining to the same study, reflected a total of 30 unique included data sets (Figure 1).

\section{Study characteristics}

The characteristics of the 30 included studies are presented in Table 1 and Supplementary Table 5. Six of the included studies were randomized clinical trials, while six were prospective non-randomized studies, and the remaining eighteen studies were retrospective non-randomized studies. These included a total of 1219 patients, with $37.7 \%$ of patients being male (from the 28 studies reporting sex) and with mean ages ranging between 11.4 and 26.6 years and with an average of 14.7 years (from the 27 studies reporting age). CBCTs were taken in all the included 
studies at two or three time points before, during and/or after orthodontic treatment in order to evaluate OIRR. Different appliances were utilized in most of the included studies with fixed appliances used in 22 studies, RME in 6 studies, surgically-assisted RME in 1 study, and Herbst appliance in 1 study. The amount of OIRR was assessed at various teeth of all types (with the exception of third molars) and both jaws.

\section{Risk of bias within studies}

The risk of bias of included non-randomized and randomized studies can be seen in Supplementary Tables 6a and 6b, respectively. According to the Cochrane Risk of Bias Tool, serious risk of bias was found in 4 out of 6 randomized trials for at least one domain with the remaining two having unclear risk of bias (Supplementary Table 6b). The remaining non-randomized studies were evaluated with the Downs and Black checklist and all of them were in serious risk of bias for at least one of the 27 domains of the tool (Supplementary Table 6a). Included studies gathered between 11 and 23 points from the maximum of 31 points to an average of 17 points. The most problematic domain categories for non-randomized studies were confounding, followed by external validity, and bias.

\section{Data synthesis - main analysis}

The main analysis of the present systematic review was conducted after pooling multiple study arms from each study and performing within-study comparisons solely from identified randomized trials that possess higher internal validity. A total of 5 different meta-analyses could be performed using the improved Paule-Mandel random-effects estimator as seen in Supplementary Table 7. No significant differences in OIRR could be found between selfligating and conventional brackets in a meta-analysis of 2 studies $(\mathrm{P}>0.5)$. A single randomized trial indicated that intrusion of upper anteriors with temporary anterior devices (TAD) placed between lateral incisor and canine resulted in greater OIRR than when the TADs were placed between second premolar and first molar, both in terms of root length $(\mathrm{MD}=0.3 \mathrm{~mm} ; 95 \% \mathrm{CI}=0.2$ to $0.5 \mathrm{~mm})$ or root volume $\left(\mathrm{MD}=6.3 \mathrm{~mm}^{3} ; 95 \% \mathrm{CI}=2.4\right.$ to $\left.10.3 \mathrm{~mm}^{3}\right)$. Finally, a randomized trial found no significant difference in OIRR between a conventional or a TAD-anchored Hybrid-Hyrax, while another randomized trial reported that Haas type RME resulted in less volumetric OIRR than Hyrax type RME (MD=-10.9 $\mathrm{mm}^{3} ; 95 \% \mathrm{CI}=-18.6$ to $\left.-3.2 \mathrm{~mm}^{3}\right)$. No additional analyses could be conducted due to the limited number of included studies. 
However, analysis of the meta-evidence with the GRADE approach (Table 2) indicated that the quality of evidence was low for the comparisons of self-ligating versus conventional appliances and for the comparison of Hyrax versus Hybrid-Hyrax RME, due to bias and imprecision. The quality of evidence supporting that anterior placed TADs lead to greater OIRR than posterior placed TADs during anterior intrusion was judged as moderate, due to bias. Finally, high quality evidence supported only the use of Haas-type RME over Hyrax-type RME in order to minimize OIRR. It should be however noted that as the majority of conclusions was drawn from single trials, further trials might change the current recommendations.

\section{Data synthesis - explorative analysis}

Furthermore, an exploratory analysis was conducted by using separate data from all available study arms of identified studies and employing a robust-variance DerSimonian-Laird random-effects model, analyzing studies on fixed appliance treatment and studies on RME separately (Table 3). As far as treatment with fixed appliances is concerned, the average linear OIRR among all 17 available studies (including 161 study arms) was found to be 0.8 $\mathrm{mm}(95 \% \mathrm{CI}=0.5$ to $1.0 \mathrm{~mm}$; Table 3; Figure 2).

Significant subgroup differences were found for various teeth, with the central incisors being affected the most $(\mathrm{OIRR}=0.8 \mathrm{~mm} ; 95 \% \mathrm{CI}=0.4$ to $1.3 \mathrm{~mm})$, followed by lateral incisors $(\mathrm{OIRR}=0.7 \mathrm{~mm} ; 95 \% \mathrm{CI}=0.4$ to 1.1 $\mathrm{mm})$, and canines $(\mathrm{OIRR}=0.4 \mathrm{~mm} ; 95 \% \mathrm{CI}=-0.3$ to $1.0 \mathrm{~mm})$. Significant differences were likewise found between anterior teeth (including incisors and canines) and posterior teeth (premolars and molars), where the OIRR of anterior teeth $(\mathrm{OIRR}=0.9 ; 95 \% \mathrm{CI}=0.6$ to 1.1$)$ was significantly greater than that of posterior teeth $(\mathrm{OIRR}=0.2 \mathrm{~mm}$; 95\% CI=-0.3 to $0.8 \mathrm{~mm}$ ). Further, significant differences were found when localizing OIRR by both tooth group (anterior or posterior) and jaw (maxilla or mandible), where the largest amount of OIRR was found for the anterior maxilla $(\mathrm{OIRR}=0.8 \mathrm{~mm} ; 95 \% \mathrm{CI}=0.6$ to $1.1 \mathrm{~mm})$, followed by the anterior mandible $(\mathrm{OIRR}=0.6 \mathrm{~mm} ; 95 \% \mathrm{CI}=-0.1$ to $1.3 \mathrm{~mm}$ ), the posterior mandible ( $\mathrm{OIRR}=0.3 \mathrm{~mm} ; 95 \% \mathrm{CI}=-0.4$ to $1.0 \mathrm{~mm}$ ), and the posterior maxilla (OIRR=0.2 $\mathrm{mm}$; $95 \% \mathrm{CI}=-0.4$ to $0.8 \mathrm{~mm}$ ). The findings were relatively robust to limiting the analysis to the subset of studies assessing OIRR solely after the completion of orthodontic treatment, although average OIRR was slightly increased (0.9 mm compared to $0.8 \mathrm{~mm}$ ). In addition, the comparison according to the jaw became now significant, with maxillary teeth being significantly more affected ( $\mathrm{OIRR}=0.9 ; 95 \% \mathrm{CI}=0.4$ to $1.3 \mathrm{~mm}$ ) compared to mandibular teeth $(\mathrm{OIRR}=0.4 \mathrm{~mm} ; 95 \% \mathrm{CI}=-0.3$ to 1.2$)$. 
Building on the initial analyses of Table 3, a further exploratory analysis was conducted, where only the maxillary anterior teeth (that are most severely affected) were included and pooled together from each study, in order to have an adequate sample, on which to perform subgroup analyses, meta-regressions, sensitivity analyses, and assess reporting biases (Table 4). As such, studies assessing OIRR after treatment completion reported significantly greater amounts of OIRR compared to studies assessing initial phases of treatment $(1.1$ and $0.5 \mathrm{~mm}$, respectively). Likewise, studies on extraction treatment reported significantly greater amounts of OIRR compared to studies on non-extraction treatment $(0.8$ and $0.5 \mathrm{~mm}$, respectively). This might be explained by potentially longer treatment duration associated with extraction treatment (Figure 3), as meta-regression showed that OIRR was significantly associated with treatment duration (with an average increase in OIRR by $0.36 \mathrm{~mm}$ for every additional year).

Additionally, sensitivity analyses indicated that retrospective studies tended to show greater OIRR than prospective studies (1.0 and $0.6 \mathrm{~mm}$, respectively) and that studies measuring OIRR at the root level tended to show greater OIRR than those at the tooth level $(1.1$ and $0.6 \mathrm{~mm}$, respectively), although both were not statistically significant $(\mathrm{P}=0.28$ and $\mathrm{P}=0.15$, respectively). In contrast, sensitivity analysis on the basis of $\mathrm{CBCT}$ voxel size indicated that studies using a small $(\leq 0.2 \mathrm{~mm})$ voxel size reported significantly greater OIRR than those using a larger $(>0.2 \mathrm{~mm})$ voxel size $(1.2$ and $0.6 \mathrm{~mm}$, respectively). Finally, no signs of reporting bias were seen with the Egger test $(\mathrm{P}>0.05)$.

As far as RME treatment is concerned, the average linear OIRR among all 3 available studies (including 20 study arms) was found to be $0.4 \mathrm{~mm}(95 \% \mathrm{CI}=-1.0$ to $1.7 \mathrm{~mm}$; Table 3), without any significant differences among teeth. As far as volumetric OIRR is concerned (Supplementary Table 8) the average OIRR after fixed appliance treatment was $15.4 \mathrm{~mm}^{3}$ ( 3 studies; $95 \% \mathrm{CI}=-4.1$ to $35.0 \mathrm{~mm}^{3}$ ), while no further analyses could be performed. The average OIRR after RME was $25.7 \mathrm{~mm}^{3}$ (4 studies; 95\% CI=6.9 to $44.5 \mathrm{~mm}^{3}$ ), with considerable differences among teeth, where first molar showed significantly greater OIRR than first premolars (40.2 and $14.8 \mathrm{~mm}^{3}$, respectively).

\section{Discussion}

\section{Summary of evidence}

The present systematic review summarizes evidence from 30 unique randomized or non-randomized studies with three-dimensional imaging of linear or volumetric OIRR during or after orthodontic treatment, which is to our 
knowledge the first systematic review on the subject. Quantitative data synthesis for this systematic review was performed on two levels, including (a) initially direct comparisons of treatment-related factors within and across only randomized trials and (b) subsequent explorative analyses with indirect comparisons across all identified randomized and non-randomized studies. Robust comparisons from randomized trials should be used to inform clinical decision making, while the explorative analyses assess evidence of observational nature to characterize the pattern of OIRR.

Direct meta-analysis pooling data from two randomized trials found no significant difference in OIRR between self-ligating and conventional brackets (Supplementary Table 7). Although the quality of existing evidence according to GRADE was low due to bias and imprecision, the results are in accordance with a previous metaanalysis of randomized trials using $2 \mathrm{D}$ imaging (35). Further, a single randomized trial indicated that intrusion of upright incisors anchored from posterior mini-implants (between second premolar and first molar) yielded more labial flaring and less OIRR than intrusion mechanics anchored anteriorly (between lateral incisor and canine) (Supplementary Table 7). This was attributed by the authors of that trial to the greater apical movement of the latter group (36), which had been proposed as a risk factor for OIRR (37).

Explorative indirect meta-analyses on the average amount of OIRR across all studies associated with fixed appliance treatment gave a pooled OIRR of $0.79 \mathrm{~mm}$ across studies with any treatment duration and a pooled OIRR of $0.86 \mathrm{~mm}$ across studies reporting on complete fixed appliance treatment from bond to debond (Table 3). This small magnitude of the average OIRR is in line with the previous systematic review of Weltman et al. (1) have probably no clinical relevance in terms of attachment loss, tooth mobility, or tooth prognosis (15). However, extreme variation is seen in the observed OIRR and statistical differences among various teeth, confirming results from previous studies that were performed with periapical or panoramic radiographs $(3,5,17)$. As such, the greatest amount of OIRR was seen for the central incisor $(0.82 \mathrm{~mm})$, followed by the lateral incisor $(0.72 \mathrm{~mm})$, the canine $(0.37 \mathrm{~mm})$, the first premolar $(0.29 \mathrm{~mm})$, and lastly the first permanent molar $(0.26 \mathrm{~mm})$. Additionally, teeth of the anterior region (up to the canine) showed significantly greater amounts of OIRR than teeth of the posterior region (premolars and molars) (0.85 and $0.24 \mathrm{~mm}$, respectively). Finally, statistically significant differences in OIRR were seen across the different regions within a jaw, with the anterior maxilla showing the greatest amoung of OIRR (0.82 $\mathrm{mm})$, followed by the anterior mandible $(0.60 \mathrm{~mm})$, the posterior mandible $(0.28 \mathrm{~mm})$, and finally the posterior maxilla $(0.22 \mathrm{~mm})$ (Table 3). However, even the greatest amount of OIRR found from CBCT data at the anterior 
maxilla seems to be less than what it was found in previous studies conducted with periapical $\mathrm{x}$ - rays $(3,17,38)$. This difference could be attributed to magnification errors and distortions due to root angulation that are very common among 2D imaging techniques (39).

As expected, limiting the analysis only to studies assessing the complete treatment from appliance placement to appliance removal (Table 3), yielded slightly greater OIRR than the original analysis of studies assessing OIRR during or after treatment $(0.86$ and $0.79 \mathrm{~mm}$, respectively), which indicates that future studies should probably measure OIRR after treatment completion to avoid underestimation of OIRR. This was confirmed by refined explorative analysis after pooling all upper anterior teeth of each study in a single group (Table 4), which actually found greater difference in the OIRR of these teeth $(1.11$ and $0.49 \mathrm{~mm}$ for complete and non-complete treatment, respectively).

Further, extraction treatment was associated with statistically greater OIRR of the upper anterior teeth than non-extraction treatment, which were 0.81 and $0.51 \mathrm{~mm}$, respectively (Table 4). A possible explanation for this would be that extraction treatment and the subsequently needed space closure takes more time to complete than nonextraction treatment (40). Moreover, treatment duration was found in meta-regression of the present study to be significantly associated with the amount of OIRR (Table 4; Figure 3), which agrees with previous data from 2D imaging $(5,10,41)$. This might explain, at least to some degree, the difference between extraction and nonextraction treatment, a finding that has also been described previously $(10,41,42)$.

Apart from fixed appliance treatment, some of the identified studies also employed CBCT to assess OIRR after treatment with RME expansion appliances. The average pooled linear OIRR associated with RME from explorative analyses was $0.36 \mathrm{~mm}$ with no significant differences across the assessed teeth (Table 3). The small magnitude of OIRR associated with RME seems to agree with the findings of Forst et al. (43), who found signs of OIRR with three-dimensional but not with $2 \mathrm{D}$ imaging, indicating that the latter approach may be worse suited to identify such small amounts of OIRR. In addition, direct evidence from randomized trials indicated that no significant difference in OIRR existed between conventional tooth-anchored Hyrax SARME and Hybrid tooth-andimplant-anchored SARME (Table 7), with low quality of evidence according to GRADE due to bias and imprecision. In contrast, conventionally-anchored Haas-type RME was associated with less OIRR than conventionally-anchored Hyrax-type RME (Table 7), which was supported by high quality of evidence according to GRADE. This agrees with previous data using 2D radiography (44), and might be possibly explained by the Haas 
expander distributing forces to both teeth and palatal vault and thereby reducing direct effects on tooth structures (45). However, these results should be interpreted with caution, as only a single randomized trial informed all direct comparisons.

A single study assessing OIRR with CBCT before and after Class II treatment with the Herbst appliance was idefntified (46), although it was omitted from quantitative data synthesis due to the absence of other similar studies. Based on the results of this study, there was evidence of statistically significant OIRR affecting the teeth upon which the Herbst appliance was anchored (upper and lower first molars), though the amount OIRR was small and not clinically significant. These findings are in accordance with previous studies that examined OIRR after Herbst treatment using 2D radiographs $(47,48)$.

Finally, as far as design and measurement characteristics are concerned, sensitivity analysis using the CBCT's voxel size showed that studies with voxel size $\leq 0.20 \mathrm{~mm}$ reported significantly greater OIRR compared to studies with greater voxel sizes (pooled OIRR: 1.15 and $0.64 \mathrm{~mm}$, respectively; Table 4). This might indicate that the latter studies had too large voxel sizes to accurately identify areas of OIRR, and therefore, small voxel sizes might be preferable to accurately diagnose OIRR. This is supported by other data indicating that the method error in measuring tooth lengths with CBCT was smaller with voxel size of $0.20 \mathrm{~mm}$ compared to both intraoral radiography and CBCT with greater voxel sizes (49). However, it must be stated that the optimal voxel size to diagnose OIRR cannot be gleamed from this systematic review and even CBCT images with a voxel size of $0.20 \mathrm{~mm}$ might be unable to identify OIRR of small magnitudes. Decisions about the appropriateness of using CBCT protocols with high-resolution and radiation dose (19) to diagnose a mostly clinically irrelevant amount of OIRR need to be based on robust evaluations of the benefit to risk ratio for the patient.

Prescribing CBCT solely for research purposes cannot be justify ethically the use of CBCT and robust evidence on whether CBCT leads to diagnosis or treatment planning with improved treatment oucomes is needed. As far as displaced maxillary canines are concerned, current evidence indicates that for most cases treatment decisions are the same with either CBCT or 2D imaging (50), while the CBCT effective dose is 15 to 140 times higher than the 2D dose (51). Only a proportion of patients might benefit in terms of changed treatment plan, while there is currently no data to support improved treatment outcomes from this change. Furthermore, CBCT can't be reliably recommended to diagnose tooth ankylosis, as although $\mathrm{CBCT}$ and histological findings coincided for some cases, false positivese were also seen (52). Therefore, currently evidence-based indications for CBCT are limited to 
some cases of maxillary displaced canines that might potentially benefit in terms of altered decision-making, even though evidence about the treatment outcomes is lacking.

\section{Strengths, limitations, and generalizability}

The strengths of the current systematic review include the a priori protocol, the comprehensive literature search including grey literature, the use of robust methods for qualitative and quantitative synthesis, and the open provision of the review's dataset to increase transparency and reproducibility (53). In addition, no language restrictions were applied, and translation was arranged for non-English papers in order to reduce language bias. Also, no restrictions concerning publication year and status were applied, thereby maximizing data yield.

Nevertheless, some limitations must also be noted, with the main one being the inclusion of retrospective studies, due to the scarcity of randomized and prospective non-randomized studies. Further, most of the included studies presented severe methodological limitations, while none of the studies used an untreated control group, since this would be difficult to justify ethically. In addition, the small number of studies that were included in several analyses and their incomplete reporting might have resulted in some analyses suffering from low statistical power. Finally, it should be noted that the present systematic review evaluated the average root resorption observed during or after treatment. In practice the clinical relevance of OIRR is directly related to the tooth's subsequent attachment loss and therefore only large magnitudes of root resorption are relevant to the patient. It might be useful in the future to categorize OIRR into clinically relevant categories of OIRR magnitude and use this as an outcome in clinical research. However, given the additive nature of many OIRR-related risk factors, evidence from this systematic review can be applied clinically to minimize OIRR in general.

Given the broad eligibity criteria that were set and the inclusion of various clinical settings in many different countries, the results of the present systematic review are applicable to the average patient, provided they correspond to the age range and treatment phase of the included studies.

\section{Conclusions}

The present systematic review summarized evidence on clinical studies assessing treatment related OIRR with CBCT. Explorative analyses on the amount and pattern of OIRR after fixed appliance treatment from all identified randomized and non-randomized studies indicated that less than $1 \mathrm{~mm}$ of OIRR is seen on the average tooth with 
CBCT. Although OIRR measured by CBCT is higher than that measured by two-dimensional imaging, it has still probably little clinical relevance, which makes the added exposure to ionizing radiation through high-resolution CBCT protocols (19) questionable in terms of risk to benefit ratio. However, considerable differences in the amount of measured OIRR are seen according to tooth category, jaw, incorporation of extraction in the treatment plan, treatment duration, and CBCT settings. These data on the pattern of OIRR associated with orthodontic treatment might be useful both in everyday clinical practice and in the design of future studies.

As far as direct comparisons from randomized studies are concerned, no differences in OIRR after fixed appliance treatment were seen between self-ligating and conventional brackets, although significant differences in OIRR after upper anterior intrusion were seen between anterior or posterior placement of TADs for anchorage. Further, OIRR after RME seemed to be similar between conventional Hyrax and hybrid Hyrax RME appliances, but less in conventional Hass appliances compared to conventional Hyrax appliances. However, these results should be interpreted with caution, due to the small number of identified randomized trials, their methodological limitations, and potential ethical implications about routine use of CBCT for OIRR diagnosis.

\section{Supplementary material}

Supplementary material is available at European Journal of Orthodontics online. 


\section{References}

1. Weltman, B., Vig, K.W., Fields, H.W., Shanker, S. and Kaizar, E.E. (2010) Root resorption associated with orthodontic tooth movement: a systematic review. American Journal of Orthodontics and Dentofacial Orthopedics, 137, 462-476.

2. Al-Qawasmi, R.A., Hartsfield, J.K. Jr., Everett, E.T., Flury, L., Liu, L., Foroud, T.M., Macri J.V. and Roberts W.E. (2003) Genetic predisposition to external apical root resorption. American Journal of Orthodontics and Dentofacial Orthopedics, 123, 242-252.

3. Parker, R.J. and Harris, E.F. (1998) Directions of orthodontic tooth movements associated with external apical root resorption of the maxillary central incisor. American Journal of Orthodontics and Dentofacial Orthopedics, 114, $677-683$.

4. Brezniak, N. and Wasserstein, A. (1993) Root resorption after orthodontic treatment: Part 2. Literature review. American Journal of Orthodontics and Dentofacial Orthopedics, 103, 138-146.

5. Apajalahti, S. and Peltola, J.S. (2007) Apical root resorption after orthodontic treatment-A retrospective study. European Journal of Orthodontics, 29, 408-412.

6. Tyrovola, J.B. and Spyropoylos, M.N. (2001) Effects of drugs and systemic factors on orthodontic treatment. Quintessence International, 32, 365-371.

7. Oyama, K., Motoyoshi, M., Hirabayashi, M., Hosoi, K., and Shimizu, N. (2007) Effects of root morphology on stress distribution at the root apex. European Journal of Orthodontics, 29, 113-117.

8. Marques, L.S., Ramos-Jorge, M.L., Rey, A.C., Armond, M.C. and Ruellas, A.C. (2010) Severe root resorption in orthodontic patients treated with the edgewise method: Prevalence and predictive factors. American Journal of Orthodontics and Dentofacial Orthopedics, 137, 384-388.

9. Linge, B.O. and Linge, L. (1983) Apical root resorption in upper anterior teeth. European Journal of Orthodontics, $5,173-183$.

10. Sameshima, G.T. and Sinclair, P.M.(2001) Predicting and preventing root resorption: Part II. Treatment factors. American Journal of Orthodontics and Dentofacial Orthopedics, 119, 511-515.

11. Han, G., Huang, S., Von den Hoff, J.W., Zeng, X. and Kuijpers-Jagtman, A.M. (2005) Root Resorption after orthodontic intrusion and extrusion: an intraindividual study. The Angle Orthodontist, 75, 912-918. 
12. Montenegro, V.C., Jones, A., Petocz, P., Gonzales, C. and Darendeliler, M.A. (2012) Physical properties of root cementum: Part 22. Root resorption after the application of light and heavy extrusive orthodontic forces: A microcomputed tomography study. American Journal of Orthodontics and Dentofacial Orthopedics, 141, 1-9.

13. Ballard, D.J., Jones, A.S., Petocz, P. and Darendeliler, M.A. (2009) Physical properties of root cementum: Part 11. Continuous vs intermittent controlled orthodontic forces on root resorption: A microcomputed tomography study. American Journal of Orthodontics and Dentofacial Orthopedics, 136, 1-8.

14. Lombardo, L., Bragazzi, R., Perissinotto, C., Mirabella, D. and Sicilliani, G. (2013) Cone-beam computed tomography evaluation of periodontal and bone support loss in extraction cases. Progress in Orthodontics, $14,29$.

15. Jönsson, A., Malmgren, O. and Levander, E. (2007) Long-term follow-up of tooth mobility in maxillary incisors with orthodontically induced apical root resorption. European Journal of Orthodontics, 29, $482-487$.

16. Makedonas, D. and Hansen, K. (2008) Diagnosis, Screening and Treatment of Root Resorption in Orthodontic Practices in Greece and Sweden. The Angle Orthodontist, 78, 248-253.

17. Sameshima, G.T. and Sinclair, P.M. (2001) Predicting and preventing root resorption: Part I. Diagnostic factors. American Journal of Orthodontics and Dentofacial Orthopedics, 119, 505-510.

18. Ren, H., Chen, J., Deng, F., Zheng, L., Liu, X. and Dong Y. (2013) Comparison of cone-beam computed tomography and periapical radiography for detecting simulated apical root resorption. The Angle Orthodontist, 83, $189-195$.

19. Ludlow, J.B., Timothy, R., Walker, C., Hunter, R., Benavides, E., Samuelson, D.B. and Scheske, M.J. (2015) Effective dose of dental CBCT-a meta analysis of published data and additional data for nine CBCT units. Dentomaxillofacial Radiology 44, 20140197.

20. Dudic, A., Giannopoulou, C., Leuzinger, M. and Kiliaridis, S. (2009) Detection of apical root resorption after orthodontic treatment by using panoramic radiography and cone-beam computed tomography of super-high resolution. . American Journal of Orthodontics and Dentofacial Orthopedics, 135, 434-437.

21. Da Silveira, H.L.D., Silveira, H.E.D., Liedke, G.S., Lermen, C.A., dos Santos, R.B. and de Figueiredo, J.A.P. (2007) Diagnostic ability of computed tomography to evaluate external root resorption in vitro. Dentomaxillofacial Radiology, 36, 393-396. 
22. Alkyalcin, S., Alexander, S.P., Silva, R.M. and English, J.D. (2015) Evaluation of three-dimensional root surface changes and resorption following rapid maxillary expansion: a cone beam computed tomography investigation. Orthodontics and Craniofacial Research, 18, 117-126.

23. Holberg, C., Steinhäuser, S., Geis, P. and Rudzki-Janson, I. (2005) Cone-Beam Computed Tomography in Orthodontics: Benefits and Limitations. Journal of Orofacial Orthopedics, 66, 434-444.

24. Higgins, J.P.T. and Green, S. (2016) Cochrane Handbook for Systematic Reviews of Interventions Version 5.1.0 [updated March 2011]. The Cochrane Collaboration, 2011. www.cochrane handbook.org (21 April 2017, date last accessed).

25. Liberati, A., et al. (2009) The PRISMA statement for reporting systematic reviews and meta-analyses of studies that evaluate health care interventions: explanation and elaboration. Journal of Clinical Epidemiology, 62, e1-34.

26. Downs, S.H. and Black, N. (1998) The feasibility of creating a checklist for the assessment of the methodological quality both of randomised and non-randomised studies of health care interventions. Journal of Epidemiology and Community Health, 52, 377-384.

27. Papageorgiou, S.N. (2014) Meta-analysis for orthodontists: part I- how to choose effect measure and statistical model. Journal of Orthodontics, 41, 317-326.

28. Veroniki, A.A., et al. (2016) Methods to estimate the between-study variance and its uncertainty in meta-analysis. Research Synthesis Methods, 7, 55-79.

29. Hedges, L.V., Tipton, E. and Johnson, M.C. (2010) Robust variance estimation in meta-regression with dependent effect size estimates. Research Synthesis Methods, 1, 39-65.

30. Samandara, A., Papageorgiou, S.N., Ioannidou-Marathiotou, I., Kavvadia-Tsatala, S. and Papadopoulos, M.A. (2018) Evaluation of orthodontically induced external root resorption following orthodontic treatment using Cone Beam Computed Tomography (CBCT): a systematic review and meta-analysis. [Data set]. Zenodo. http://doi.org/10.5281/zenodo.1185732.

31. Egger, M., Davey, S.D., Schneider, M. and Minder, C. (1997) Bias in meta-analysis detected by a simple, graphical test. British Medical Journal, 315, 629-634.

32. Guyatt, G.H., Oxman, A.D., Schünemann, H.J., Tugwell, P. and Knottnerus, A. (2011) GRADE guidelines: a new series of articles in the Journal of Clinical Epidemiology. Journal of Clinical Epidemiology, 64, 380-382. 
33. Papageorgiou, S.N. (2014) Meta-analysis for orthodontists: Part II-is all that glitters gold? Journal of Orthodontics, 41, 327-336.

34. Lund, H., Gröndahl, K., Hansen, K. and Gröndahl, H.G. (2012) Apical root resorption during orthodontic treatment. A prospective study using cone beam CT. The Angle Orthodontist, 82, 480-487.

35. Papageorgiou, S.N., Konstantinidis, I., Papadopoulou, K., Jäger, A. and Bourauel, C. (2014) Clinical effects of preadjusted edgewise orthodontic brackets: a systematic review and meta-analysis. European Journal of Orthodontics, $36,350-363$.

36. Aras, I. and Tuncer, A.V. (2016) Comparison of anterior and posterior mini-implant-assisted maxillary incisor intrusion: Root resorption and treatment efficiency. The Angle Orthodontist, 86, 746-752.

37. Dermaut, L.R. and De Munck, A. (1986) Apical root resorption of upper incisors caused by intrusive tooth movement: a radiographic study. American Journal of Orthodontics and Dentofacial Orthopedics, 90, 321-326.

38. McFadden, M., Engstrom, C., Engstrom, H and Anholm, M. (1989) A study of the relationship between incisor intrusion and root shortening. American Journal of Orthodontics and Dentofacial Orthopedics, 96, 390-396.

39. Tieu, L.D., Saltaii, H., Normando, D. and Flores-Mir, C. (2014) Radiologically determined orthodontically induced external apical root resorption in incisors after non-surgical orthodontic treatment of class II division 1 malocclusion: a systematic review. Progress in Orthodontics, 15, 48.

40. Papageorgiou, S.N., Höchli, D. and Eliades, T. (2017) Outcomes of comprehensive fixed appliance orthodontic treatment: A systematic review with meta-analysis and methodological overview. Korean Journal of Orthodontics;47:401-413.

41. Maues, C.P., do Nascimento, R.R. and Vilella Ode V. (2015) Severe root resorption resulting from orthodontic treatment: prevalence and risk factors. Dental Press Journal of Orthodontics, 20, 52-58.

42. McNab, S., Battistutta, D., Tanerne, A. and Symons, A.L. (2000) External apical root resorption following orthodontic treatment. The Angle Orthodontist, 70, 227-232.

43. Forst, D., Nijjar, S., Khaled, Y., Lagravere, M. and Flores-Mir, C. (2014) Radiographic assessment of external root resorption associated with jackscrew-based maxillary expansion therapies: a systematic review. European Journal of Orthodontics, 36, 576-585.

44. Odenrick, L., Karlander, E.L., Pierce, A. and Kretschmar, U. (1991) Surface resorption following two forms of rapid maxillary expansion. European Journal of Orthodontics, 13, 264-270. 
45. Haas, A.J. (1965) The treatment of maxillary deficiency by opening the midpalatal suture. The Angle Orthodontist, $35,200-217$.

46. Schwarz, J.P., Raveli, T.B., Almeida, K.C., Schwarz-Filho, H.O. and Raveli, D.B. (2015) Cone beam computed tomography study of apical root resorption induced by Herbst appliance. Journal of Applied Oral Science, 23, 479485.

47. Nasiopoulos, A.T., Athanasiou, A.E., Papadopoulos, M.A., Kolokithas, G. and Ioannidou, I. (2006) Premolar root changes following treatment with the banded Herbst. Journal of orofacial orthopedics, 67, 261-271.

48. Kinzinger, G.S., Savvaidis, S., Gross, U., Gülden, N., Ludwig, B. and Lisson J. (2011) Effects of Class II treatment with a banded Herbst appliance on root lengths in the posterior dentition. American Journal of Orthodontics and Dentofacial Orthopedics, 139, 465-469.

49. Lund, H., Gröndahl, K. and Gröndahl, H.G. (2010) Cone beam computed tomography for assessment of root length and marginal bone level during orthodontic treatment. The Angle Orthodontist, 80, 466-473.

50. Christell, H., Birch, S., Bondemark, L., Horner, K., Lindh, C.; SEDENTEXCT consortium. (2018) The impact of Cone Beam CT on financial costs and orthodontists' treatment decisions in the management of maxillary canines with eruption disturbance. European Journal of Orthodontics, 40, 65-73.

51. Kadesjö, N., Lynds, R., Nilsson, M. and Shi, X.Q. (2018) Radiation dose from X-ray examinations of impacted canines: cone beam CT vs two-dimensional imaging. Dentomaxillofacial Radiology, 47, 20170305.

52. Ducommun, F., Bornstein, M.M., Bosshardt, D., Katsaros, C. and Dula, K. (2018) Diagnosis of tooth ankylosis using panoramic views, cone beam computed tomography, and histological data: a retrospective observational case series study. European Journal of Orthodontics, [Epub ahead of print]. doi: 10.1093/ejo/cjx063.

53. Papageorgiou, S.N. and Cobourne, M.T. (2018) Data sharing in orthodontic research. Journal of Orthodontics, 45, $1-3$. 


\section{Figure \& Table Legends}

Figure 1. Flowdiagram for the identification and selection of studies in this systematic review.
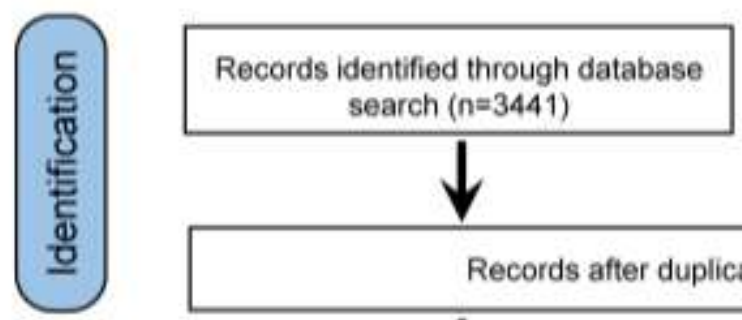

Additional records identified through other sources $(n=1)$
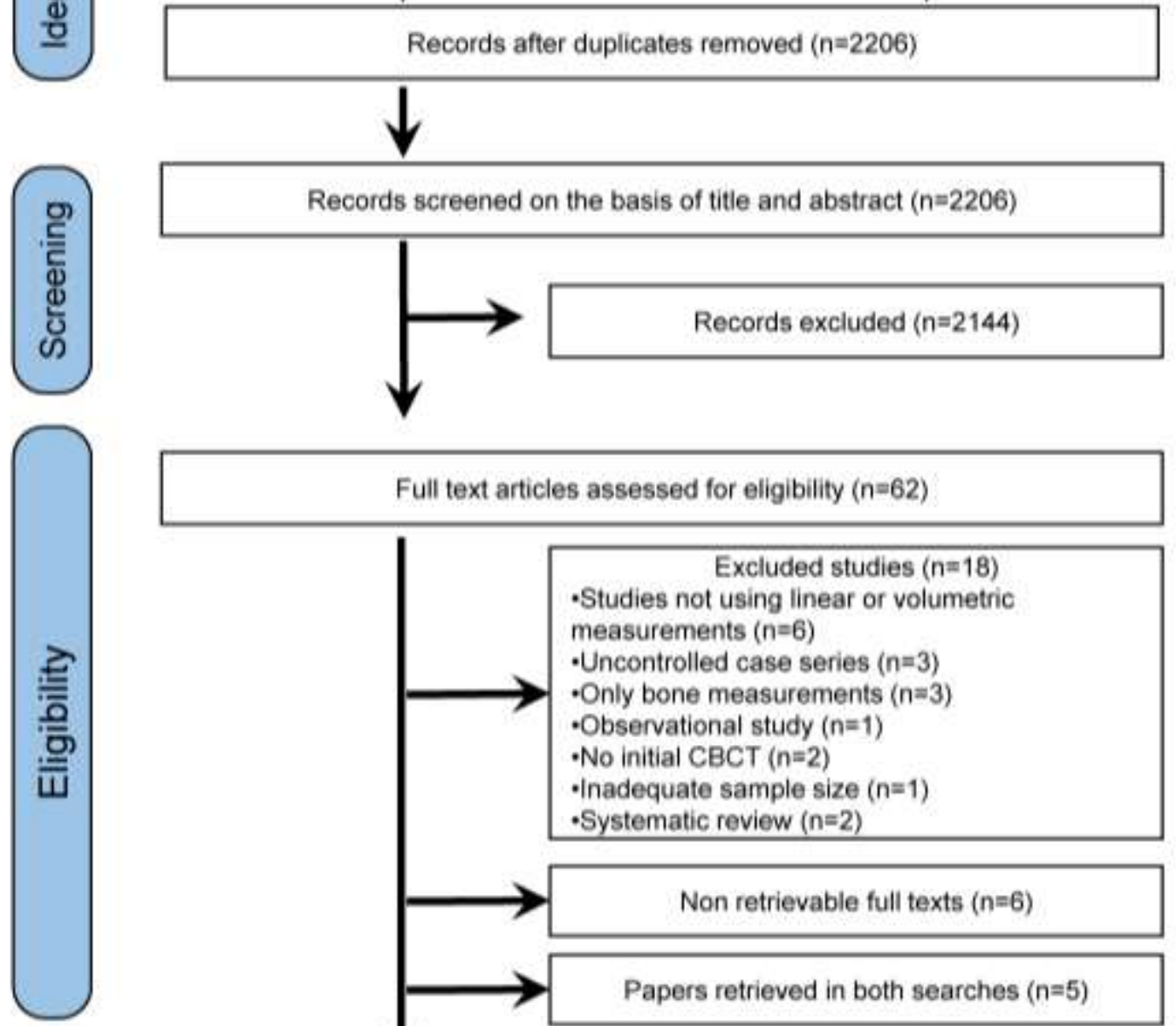

Excluded studies $(n=18)$

-Studies not using linear or volumetric measurements $(n=6)$

- Uncontrolled case series $(n=3)$

- Only bone measurements $(n=3)$

- Observational study $(n=1)$

-No initial CBCT $(n=2)$

-Inadequate sample size $(n=1)$

-Systematic review $(n=2)$

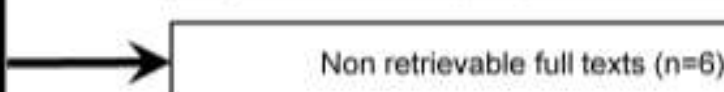

Papers retrieved in both searches $(n=5)$

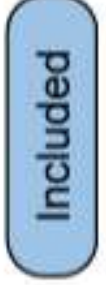

Studies included in the systematic review ( $n=33 ; 30$ datasets)

Studies included in the meta-analysis $\left(n=27^{*}\right)$ 
Figure 2. Contour-enhanced funnel plot for the pooled orthodontically induced root resorption across all randomized and non-randomized studies included in the explorative analyses (Table 7).

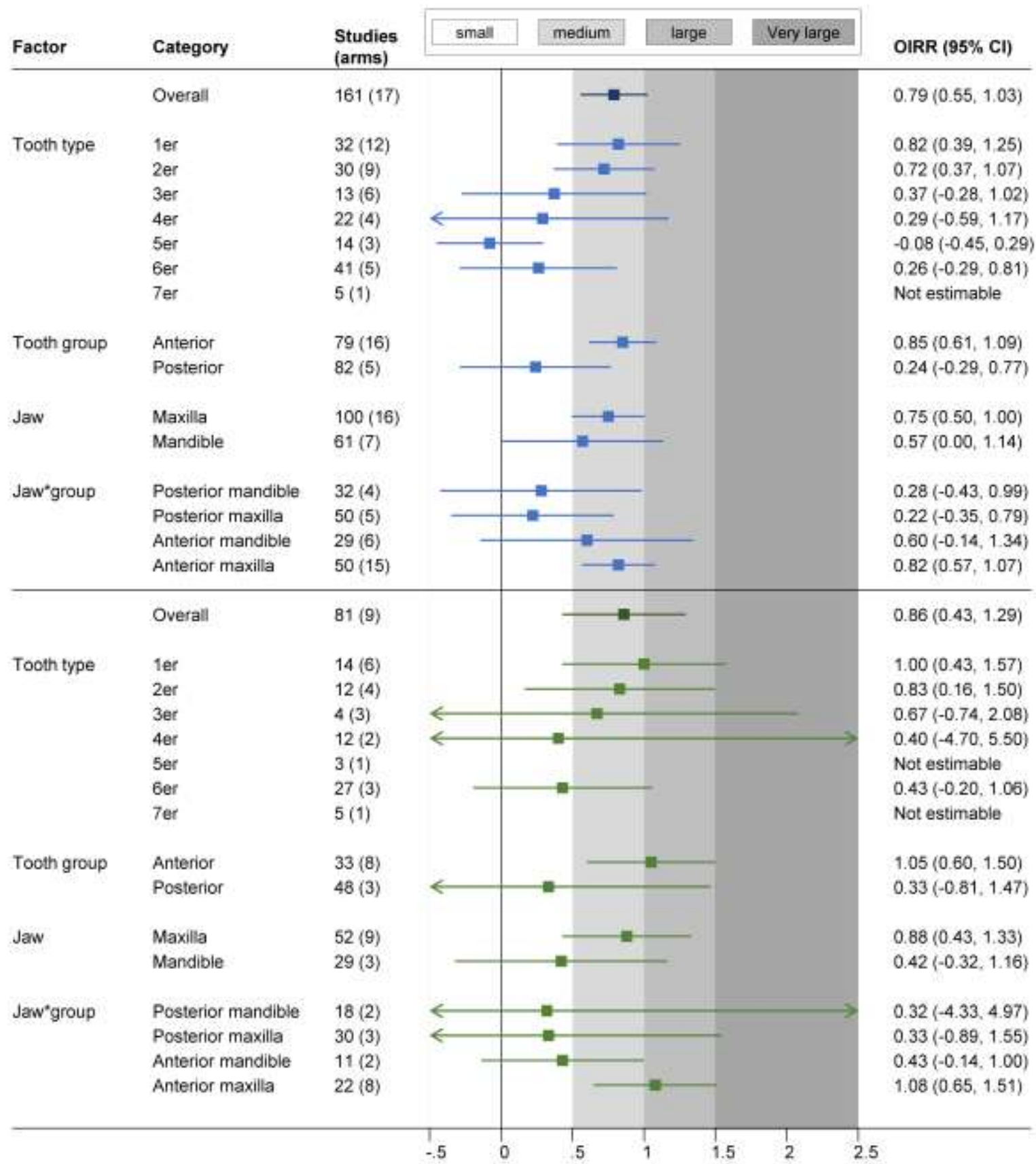


Figure 3. Random-effects meta-regression of the pooled orthodontically induced root resorption of the upper anterior teeth according to the mean duration of orthodontic treatment (Table 8).

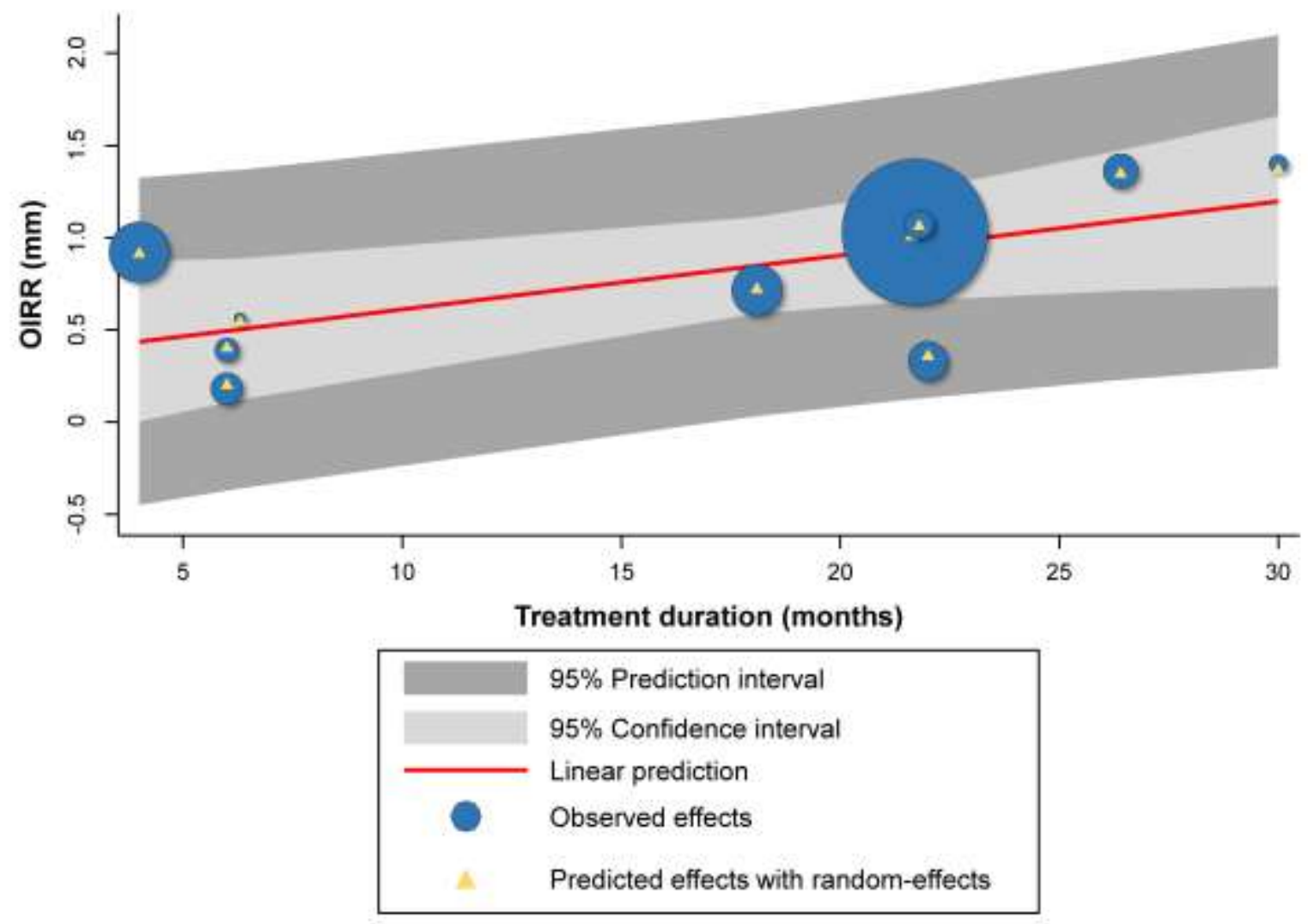


Table 1. Characteristics of included studies regarding patients and interventions.

\begin{tabular}{|c|c|c|c|c|c|c|}
\hline Study & Design & Characteristics of patients & $\begin{array}{l}\text { No Patients (M/F); } \\
\text { mAge (yrs) }\end{array}$ & Intervention & TxDur & $\mathrm{COI}$ \\
\hline $\begin{array}{l}\text { Abdel-Kader } \\
2016\end{array}$ & rNRS; Uni; EGY & PM1 Ex \& C retraction & $16(6 / 10) ; 16.4$ & FFA; E-chain & $6.3 \mathrm{mos}$ & NR \\
\hline Ahn 2013 & rNRS; Uni; KOR & $\begin{array}{l}\text { Cl. I; d-a protrusion; 4PM Ex; } \\
\text { en masse Retr; }\end{array}$ & $37(0 / 37) ; 26.6$ & 22-slot; Roth; TPA/HG; E-chain (200g) & $21.7 \mathrm{mos}$ & NR \\
\hline Ajmera 2014 & pNRS; Uni; IND & $\begin{array}{l}\text { Max-ant. proclination; PM1 } \\
\text { Ex; en masse Retr /Intr. }\end{array}$ & $48(21 / 27) ; 13.6$ & 22-slot; MBT; TADs (200g) & NR & NR \\
\hline $\begin{array}{l}\text { Alexander 2014; } \\
\text { Akyalcin } 2015 \\
\end{array}$ & rNRS; Uni; USA & ME need & $24(10 / 14) ; 12.8$ & Tooth-Anc RME (0.25mm/day; 5mos Retw) & $4.8 \mathrm{mos}$ & NR \\
\hline Aras 2016 & RCT; Uni; TUR & $\begin{array}{l}\text { Cl.I or II; OB } \geq 5 \mathrm{~mm} \text {; max. ant. } \\
\text { Intr; }\end{array}$ & $\begin{array}{l}\text { Gp1: } 16(6 / 10) ; 19.3 \\
\text { Gp2: } 16(6 / 10) ; 19.0\end{array}$ & $\begin{array}{l}\text { Gp1: } 2 \text { Mls between I2-C; SS segmental wire; E-chain } \\
\text { Gp2: } 2 \text { Mls between PM2-M1; Burstone TMA IntrArch } \\
\text { (40g/side) }\end{array}$ & 4.0 mos & NR \\
\hline Baysal 2012 & rNRS; Uni; TUR & ME need & $25(11 / 14) ; 12.7$ & Tooth-Anc RME (0.5mm/day) & NR & NR \\
\hline Bolerjack 2005 & rNRS; pract; USA & $\begin{array}{l}\text { Non-Ex/Ex (4 PMs); sliding } \\
\text { mechanics }\end{array}$ & $95(41 / 54) ; 12.7$ & 22-slot; Roth & $26.4 \mathrm{mos}$ & NR \\
\hline $\begin{array}{l}\text { Castro 2013; } \\
\text { Castro 2015 }\end{array}$ & rNRS; pract; BRA & Cl. I Non-Ex & $30(11 / 19) ; 13.0$ & 22-slot; Roth & $22.0 \mathrm{mos}$ & NR \\
\hline Dindaroglu 2016 & RCT; Uni; TUR & ME need & $\begin{array}{l}\text { Gp1/2 33(17/16); } 12.8 \\
\text { Gp1: } 16(\mathrm{NR}) ; 12.9 \\
\text { Gp2: } 17(\mathrm{NR}) ; 12.8\end{array}$ & $\begin{array}{l}\text { Gp1/2 }(0.5 \mathrm{~mm} / \text { day; 6mos Retw }) \\
\text { Gp1: Tooth-Anc Hyrax RME } \\
\text { Gp2: Tooth-Anc Haas RME }\end{array}$ & $6.0 \mathrm{mos}$ & NR \\
\hline Forst 2015 & $\mathrm{RCT}^{*}$; Uni; CAN & ME need & $\begin{array}{l}\text { Gp1: } 20(5 / 15) ; 14.1 \\
\text { Gp2: } 21(8 / 13) ; 14.2 \\
\text { Gp3: } 21(6 / 15) ; 12.9\end{array}$ & $\begin{array}{l}\text { Gp1: Tooth-anch RME }\left(0.5 \mathrm{~mm} / \text { day; 6mos Retw; } 6 \text { mos } \operatorname{Ret}_{w / o}\right) \\
\text { Gp2: Bone-anch RME }\left(0.25 \mathrm{~mm} / \text { day; 6mos Retw } 6 \text { mos }_{\text {Retw/o }}\right) \\
\text { Gp3: No Tx }\end{array}$ & $12.0 \mathrm{mos}^{\$}$ & NR \\
\hline Guo 2016 & rNRS; Uni; CHN & - & $174(68 / 106) ; 14.1$ & FFA (SW); 'light forces' & 20.6 mos & None \\
\hline Harris 2015 & rNRS; Uni; TUR & ME need & $\begin{array}{l}\text { Gp1: } 20(8 / 12) ; 13.8 \\
\text { Gp2: } 20(7 / 13) ; 13.8\end{array}$ & $\begin{array}{l}\text { Gp1: Tooth-anch RME }(0.4 \mathrm{~mm} / \text { day; 3mos Retw }) \\
\text { Gp2: Bone-anch RME }(0.4 \mathrm{~mm} / \text { day; 3mos Retw) }\end{array}$ & $3.0 \mathrm{mos}^{\$}$ & NR \\
\hline Johnson 2010 & rNRS; pract; USA & $\begin{array}{l}\text { FFA (1- or 2-phase); Ex/Non- } \\
\text { Ex }\end{array}$ & $\begin{array}{l}\text { Gp1: } 24(11 / 13) ; 12.7 \\
\text { Gp2: } 33(10 / 23) ; 19.1\end{array}$ & $\begin{array}{l}\text { Gp1: 18-slot; MBT } \\
\text { Gp2: 18-slot; MBT+Suresmile }\end{array}$ & $\begin{array}{l}\text { Gp1: } 19.5 \text { mos } \\
\text { Gp2: } 13.9 \text { mos }\end{array}$ & NR \\
\hline Kau 2011 & pNRS; Uni; USA & Cl.I; PMs Ex & $14(\mathrm{NR}) ; 20.3$ & FFA (SW) + vibration & $6.0 \mathrm{mos}$ & NR \\
\hline Kaylar 2016 & RCT; Uni; TUR & ME need & $\begin{array}{l}\text { Gp1: } 10(6 / 4) ; 19.3 \\
\text { Gp2: } 10(3 / 7) ; 19.2\end{array}$ & $\begin{array}{l}\text { Gp1: Tooth-anch SARME }\left(0.5 \mathrm{~mm} / \text { day; } 6 \text { mos Ret }_{w}\right) \\
\text { Gp2: Bone-anch SARME }(0.5 \mathrm{~mm} / \text { day; } 6 \text { mos Retw })\end{array}$ & $6.0 \mathrm{mos}^{\$}$ & None \\
\hline Leite 2012 & RCT; Uni; BRA & $\begin{array}{l}\text { Cl. I; moderate crowding; } \\
\text { Non-Ex }\end{array}$ & $\begin{array}{l}\text { Gp1: } 11(6 / 5) ; 20.6^{£} \\
\text { Gp2: } 8(2 / 6) ; 20.6^{£}\end{array}$ & $\begin{array}{l}\text { Gp1: 22-slot; SLB } \\
\text { Gp2: 22-slot; CLB }\end{array}$ & 6.0 mos & NR \\
\hline Li 2013 & rNRS; Uni; CHN & Cl. I-II; molar intrusion & $12(4 / 8) ; 24.3$ & TADs; E-chain (150g) & $6.0 \mathrm{mos}$ & NR \\
\hline Liu 2016 & RCT; Hosp; CHN & Ex/Non-Ex & $\begin{array}{l}\text { Gp1: } 25(11 / 14) ; 15.3 \\
\text { Gp2: } 25(9 / 16) ; 15.2\end{array}$ & $\begin{array}{l}\text { Gp1: 22-slot; SLB } \\
\text { Gp2: 22-slot; CLB }\end{array}$ & NR & NR \\
\hline Lombardo 2013 & rNRS; pract; ITA & Cl. II/1; Ex (4 PMs) /Non-Ex & $22(10 / 12) ; 11.4$ & Tweed-Merrifield technique & $20.5 \mathrm{mos}$ & NR \\
\hline Lynch 2011 & rNRS; pract; USA & Cl. I-II; Ex/Non-Ex & $122(53 / 69) ; 13.2$ & 22-slot; loops/E-chains & $21.8 \mathrm{mos}$ & NR \\
\hline Ma 2013 & pNRS; Uni; CHN & ME need & $32(0 / 32) ; 14.3$ & Magnetic RME (increment/month) & $9.3 \mathrm{mos}$ & NR \\
\hline Nakada 2016 & rNRS; Uni; JPN & 4 PM Ex & $30(8 / 22) ; 21.9$ & FFA & NR & NR \\
\hline Nimeri 2014 & pNRS; Uni; USA & Cl. I; crowding; PM Ex & 20 (5/15); NR & $F F A+L L L T$ & NR & $\begin{array}{l}\text { Com } \\
\mathrm{m}\end{array}$ \\
\hline Patel 2012 & rNRS; pract; USA & FFA (1- phase); Ex/Non-Ex & $\begin{array}{l}\text { Gp1: } 32(16 / 16) ; 12.6 \\
\text { Gp2: } 34(11 / 23) ; 18.9\end{array}$ & $\begin{array}{l}\text { Gp1: 18-slot; MBT } \\
\text { Gp2: 18-slot; MBT+Suresmile }\end{array}$ & $\begin{array}{l}\text { Gp1: } 18.1 \mathrm{mos} \\
\text { Gp2: } 14.2 \mathrm{mos}\end{array}$ & NR \\
\hline
\end{tabular}




\begin{tabular}{|c|c|c|c|c|c|c|}
\hline Schwarz 2015 & rNRS; Uni; BRA & Cl. II; OJ > $5 \mathrm{~mm}$ & $23(11 / 12) ; 15.8$ & Herbst appliance & $8.5 \mathrm{mos}$ & NR \\
\hline $\begin{array}{l}\text { Oliveira 2011; } \\
\text { Oliveira 2016 }\end{array}$ & pNRS; Uni; BRA & $\begin{array}{l}\text { Cl. I-II/1; protrusion; Mx PM1 } \\
\text { Ex }\end{array}$ & $11(5 / 6) ;$ adult & FFA; omega loops & NR & NR \\
\hline Wang 2013 & pNRS; Uni; CHN & $\begin{array}{l}\text { Skeletal Cl. III; pre-surgical } \\
\text { decompensation need; Non- } \\
\text { Ex }\end{array}$ & $\begin{array}{l}\text { Gp1: } 30(14 / 16) ; 24.8 \\
\text { Gp2: } 26 \text { (17/9); } 23.5\end{array}$ & $\begin{array}{l}\text { Gp1: FFA } \\
\text { Gp2: FFA + corticotomy }\end{array}$ & $\begin{array}{l}\text { Gp1: } 13.3 \text { mos } \\
\text { Gp2: } 7.8 \text { mos }\end{array}$ & None \\
\hline Wang 2015 & rNRS; Uni; CHN & $\begin{array}{l}\text { Skeletal Cl. III; pre-surgical } \\
\text { decomp-ensation need; Non- } \\
\text { Ex }\end{array}$ & 30 (13/17); adult & FFA; MBT & $8.7 \mathrm{mos}$ & NR \\
\hline Wen 2016 & rNRS; Uni; CHN & PM Ex \& space closure; TAD & $12(3 / 9)$; adult & FFA & $30.0 \mathrm{mos}$ & NR \\
\hline Yang 2016 & rNRS; Uni; CHN & 4 PM Ex; ant. Retr. & 7 (NR); 22.3 yrs & FFA & NR & NR \\
\hline
\end{tabular}

$£$ for both groups

*randomization was performed for another study, not on the basis of root resorption

$\$$ period including a retention period about 12 mos

$\dagger$ Right and left teeth of the same category were averaged for analyses.

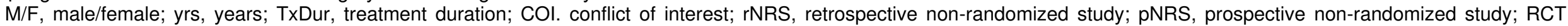

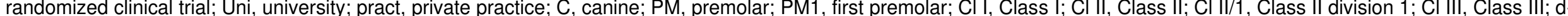

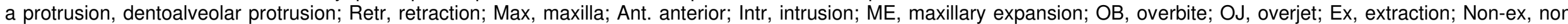

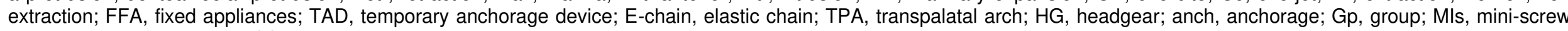

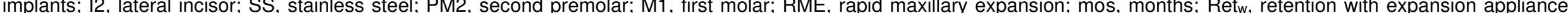

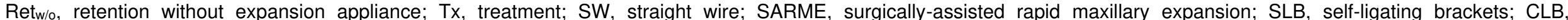
conventional brackets; LLLT, low level light therapy; NR, not reported; Comm, commercial. 
Table 2. Summary of findings table according to the GRADE approach.

\begin{tabular}{|c|c|c|c|c|c|}
\hline \multirow[b]{2}{*}{$\begin{array}{l}\text { Outcome } \\
\text { Trials (patients) }\end{array}$} & \multicolumn{3}{|c|}{ Anticipated absolute effects } & \multirow[b]{2}{*}{$\begin{array}{l}\text { Quality of the } \\
\text { evidence (GRADE) }\end{array}$} & \multirow[b]{2}{*}{ What happens } \\
\hline & Reference* & Experimental & $\begin{array}{l}\text { Difference for experimental } \\
(95 \% \mathrm{Cl})\end{array}$ & & \\
\hline & $\begin{array}{l}\text { Conventional } \\
\text { brackets }\end{array}$ & $\begin{array}{l}\text { Self-ligating } \\
\text { brackets }\end{array}$ & & & \\
\hline \multirow[t]{2}{*}{$\begin{array}{l}\text { OIRR (linear) of upper anteriors after comprehensive Tx } \\
2 \text { trials ( } 276 \text { teeth) }\end{array}$} & $\begin{array}{l}0.8 \mathrm{~mm} \text { OIRR } \\
\text { on average }\end{array}$ & + & $\begin{array}{l}<0.1 \mathrm{~mm} \text { more OIRR }(0.2 \\
\mathrm{mm} \text { less to } 0.3 \mathrm{~mm} \text { more })\end{array}$ & $\begin{array}{l}\bigoplus \oplus \Theta \Theta \text { low }^{\mathrm{b}, \mathrm{c}} \\
\text { due to bias, imprecision }\end{array}$ & $\begin{array}{l}\text { Little to no difference } \\
\text { in OIRR }\end{array}$ \\
\hline & $\begin{array}{l}\text { Posterior } \\
\text { TADS }\end{array}$ & Anterior TADs & & & \\
\hline $\begin{array}{l}\text { OIRR (linear) of upper anteriors after } 4 \text { mos intrusion } \\
1 \text { trial (128 teeth) }\end{array}$ & $\begin{array}{l}0.8 \mathrm{~mm} \text { OIRR } \\
\text { on average }\end{array}$ & - & $\begin{array}{l}0.3 \mathrm{~mm} \text { more OIRR (0.2 to } \\
0.5 \mathrm{~mm} \text { more) }\end{array}$ & $\begin{array}{l}\bigoplus \oplus \oplus \ominus \text { moderate }^{b} \\
\text { due to bias }\end{array}$ & $\begin{array}{l}\text { Probably more OIRR } \\
\text { with anterior TADs }\end{array}$ \\
\hline \multirow[t]{2}{*}{$\begin{array}{l}\text { OIRR (volumetric) of upper anteriors after } 4 \text { mos intrusion } \\
1 \text { trial (128 teeth) }\end{array}$} & $\begin{array}{l}12.9 \mathrm{~mm}^{3} \\
\text { OIRR on } \\
\text { average }\end{array}$ & - & $\begin{array}{l}6.3 \mathrm{~mm}^{3} \text { more OIRR }(2.4 \text { to } \\
\left.10.3 \mathrm{~mm}^{3} \text { more }\right)\end{array}$ & $\begin{array}{l}\bigoplus \bigoplus \oplus \ominus \text { moderate } \\
\text { due to bias }\end{array}$ & $\begin{array}{l}\text { Probably more OIRR } \\
\text { with anterior TADs }\end{array}$ \\
\hline & $\begin{array}{l}\text { Tooth-borne } \\
\text { RME (Hyrax) }\end{array}$ & $\begin{array}{l}\text { Hybrid-borne } \\
\text { RME (Hyrax) }\end{array}$ & & & \\
\hline $\begin{array}{l}\text { OIRR (linear) of upper posteriors after RME \& retention } \\
1 \text { trial (100 teeth) }\end{array}$ & $\begin{array}{l}0.5 \mathrm{~mm} \text { OIRR } \\
\text { on average }\end{array}$ & & $\begin{array}{l}0.1 \mathrm{~mm} \text { more OIRR }(0.1 \mathrm{~mm} \\
\text { less to } 0.3 \text { more })\end{array}$ & $\begin{array}{l}\bigoplus \bigoplus \Theta \Theta \text { low } \mathrm{b}, \mathrm{c} \\
\text { due to bias, imprecision }\end{array}$ & $\begin{array}{l}\text { Little to no difference } \\
\text { in OIRR }\end{array}$ \\
\hline \multirow[t]{2}{*}{$\begin{array}{l}\text { OIRR (volumetric) of upper posteriors after RME \& retention } \\
1 \text { trial (37 teeth) }\end{array}$} & $\begin{array}{l}49.3 \mathrm{~mm}^{3} \\
\text { OIRR on } \\
\text { average }\end{array}$ & & $\begin{array}{l}17.8 \mathrm{~mm}^{3} \text { less OIRR ( } 47.5 \\
\left.\mathrm{~mm}^{3} \text { less to } 11.9 \mathrm{~mm}^{3} \text { more }\right)\end{array}$ & $\begin{array}{l}\oplus \oplus \ominus \ominus \text { low } \text { b,c } \\
\text { due to bias, imprecision }\end{array}$ & $\begin{array}{l}\text { Little to no difference } \\
\text { in OIRR }\end{array}$ \\
\hline & $\begin{array}{l}\text { Tooth-borne } \\
\text { RME (Hyrax) }\end{array}$ & $\begin{array}{l}\text { Tooth-borne } \\
\text { RME (Haas) }\end{array}$ & & & \\
\hline $\begin{array}{l}\text { OIRR (volumetric) of upper posteriors after RME \& retention } \\
1 \text { trial (396 teeth) }\end{array}$ & $\begin{array}{l}47.8 \mathrm{~mm}^{3} \\
\text { OIRR on } \\
\text { average }\end{array}$ & 1 & $\begin{array}{l}10.9 \mathrm{~mm}^{3} \text { less OIRR }(3.2 \text { to } \\
\left.18.6 \mathrm{~mm}^{3} \text { less }\right)\end{array}$ & $\oplus \bigoplus \oplus \oplus$ high & $\begin{array}{l}\text { Probably less OIRR } \\
\text { with Haas }\end{array}$ \\
\hline
\end{tabular}

Orthodontically induced root resorption assessed with cone-beam computed tomography.

Patient or population: adolescent / adult patients receiving comprehensive fixed appliance orthodontic treatment, maxillary anterior intrusion, or rapid maxillary expansion.

Settings: university clinics \& hospital (Brazil, Canada, China, Turkey).

*Reponse is based on random-effects meta-analytical pooling of the corresponding reference groups among included studies.

aStarts from "high", due to the inclusion of randomized studies.

bDowngraded further by one point due to serious limitations (high risk of bias).

'Downgraded by one due to imprecision originating from the inclusion of a small sample size.

Abbreviations

$\mathrm{Cl}$, confidence interval; GRADE, Grading of Recommendations Assessment, Development and Evaluation; OIRR, orthodontically induced root resorption; RME, rapid maxillary expansion; TAD, temporary anchorage device. 
Table 3. Explorative analysis of linear OIRR including multiple measurements from all included studies.

\begin{tabular}{|c|c|c|c|c|c|c|c|c|c|c|c|c|}
\hline \multirow{3}{*}{\begin{tabular}{|l|l|} 
& \\
& Factor \\
Any studies
\end{tabular}} & \multirow[b]{2}{*}{ Group } & \multicolumn{5}{|c|}{ Fixed-appliance Tx } & \multicolumn{6}{|c|}{ Rapid maxillary expansion } \\
\hline & & \multirow[t]{2}{*}{ Arms } & \multicolumn{2}{|c|}{ Studies Mean } & \multirow[t]{2}{*}{$95 \% \mathrm{Cl}$} & \multirow[t]{2}{*}{ PsG } & \multirow[t]{2}{*}{ Arms } & \multicolumn{3}{|c|}{ Studies Mean } & \multirow{2}{*}{$95 \% \mathrm{Cl}$} & \multirow[t]{2}{*}{ PsG } \\
\hline & & & & & & & & & & & & \\
\hline & Overall & 161 & 17 & 0.79 & $0.54,1.03$ & & 20 & 3 & & 0.36 & $-0.97,1.69$ & \\
\hline & & & & & & & & & & & & \\
\hline Tooth type & $1 \mathrm{er}$ & 32 & 12 & 0.82 & $0.38,1.26$ & 0.04 & - & - & & & & 0.51 \\
\hline & $2 e r$ & 30 & 9 & 0.72 & $0.36,1.07$ & & - & - & & & & \\
\hline & 3er & 13 & 6 & 0.37 & $-0.28,1.02$ & & - & - & & & & \\
\hline & $4 e r$ & 22 & 4 & 0.29 & $-0.59,1.17$ & & 7 & 3 & & 0.35 & $-1.26,1.97$ & \\
\hline & $5 e r$ & 14 & 3 & -0.08 & $-0.46,0.30$ & & 1 & 1 & & NE & & \\
\hline & $6 e r$ & 41 & 5 & 0.26 & $-0.30,0.81$ & & 12 & 3 & & 0.24 & $-0.87,1.35$ & \\
\hline & $7 e r$ & 5 & 1 & NE & & & - & - & & & & \\
\hline & & & & & & & & & & & & \\
\hline Tooth group & Anterior & 79 & 16 & 0.85 & $0.62,1.08$ & 0.08 & - & - & & & & ne \\
\hline & Posterior & 82 & 5 & 0.24 & $-0.29,0.77$ & & Same & & & & & \\
\hline & & & & & & & & & & & & \\
\hline Jaw & Maxilla & 100 & 16 & 0.75 & $0.49,1.00$ & 0.77 & Same & & & & & ne \\
\hline & Mandible & 61 & 7 & 0.57 & $0.01,1.13$ & & - & - & & & & \\
\hline & & & & & & & & & & & & \\
\hline Jaw*group & $\begin{array}{l}\text { Posterior } \\
\text { mandible }\end{array}$ & 32 & 4 & 0.28 & $-0.42,0.98$ & 0.06 & - & - & & & & \\
\hline & Posterior maxilla & 50 & 5 & 0.22 & $-0.35,0.78$ & & Same & & & & & \\
\hline & Anterior mandible & 29 & 6 & 0.6 & $-0.14,1.34$ & & - & F & & & & \\
\hline & Anterior maxilla & 50 & 15 & 0.82 & $0.58,1.07$ & & - & - & & & & \\
\hline Only studies with & complete $\mathrm{Tx}$ & & & & & & & & & & & \\
\hline & Overall & 81 & 9 & 0.86 & $0.42,1.30$ & & 20 & 3 & & 0.36 & $-0.97,1.69$ & \\
\hline & & & & & & & & & & & & \\
\hline Tooth type & 1er & 14 & 6 & 1 & $0.44,1.57$ & 0.1 & - & f & & & & 0.51 \\
\hline & 2er & 12 & 4 & 0.83 & $0.18,1.49$ & & f & F & & & & \\
\hline & $3 e r$ & 4 & 3 & 0.67 & $-0.74,2.08$ & & - & - & & & & \\
\hline & $4 e r$ & 12 & 2 & 0.4 & $-4.68,5.49$ & & 7 & 3 & & 0.35 & $-1.26,1.97$ & \\
\hline & $5 e r$ & 3 & 1 & $\mathrm{NE}$ & & & 1 & 1 & & NE & & \\
\hline & $6 e r$ & 27 & 3 & 0.43 & $-0.20,1.06$ & & 12 & 3 & & 0.24 & $-0.87,1.35$ & \\
\hline & $7 e r$ & 5 & 1 & $\mathrm{NE}$ & & & - & F & & & & \\
\hline & & & & & & & & & & & & \\
\hline Tooth group & Anterior & 33 & 8 & 1.05 & $0.59,1.51$ & 0.12 & - & - & & & & - \\
\hline & Posterior & 48 & 3 & 0.33 & $-0.82,1.47$ & & Same & & & & & \\
\hline & & & & & & & & & & & & \\
\hline Jaw & Maxilla & 52 & 9 & 0.88 & $0.43,1.33$ & 0.1 & Same & & & & & - \\
\hline & Mandible & 29 & 3 & 0.42 & $-0.33,1.17$ & & - & - & & & & \\
\hline & & & & & & & & & & & & \\
\hline Jaw*group & $\begin{array}{l}\text { Posterior } \\
\text { mandible }\end{array}$ & 18 & 2 & 0.32 & $-4.33,4.97$ & 0.14 & & & & & & \\
\hline & Posterior maxilla & 30 & 3 & 0.33 & $-0.89,1.55$ & & Same & & & & & \\
\hline & Anterior mandible & 11 & 2 & 0.43 & $-0.18,1.03$ & & - & - & & & & \\
\hline & Anterior maxilla & 22 & 8 & 1.08 & $0.65,1.52$ & & 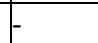 & F & & & & \\
\hline
\end{tabular}

* Comparisons of SARME \& Herbst were informed only from 1 study each and are omitted.

NE, not estimated. 
Table 4. Explorative analysis of pooled linear OIRR for maxillary anterior teeth/segments from all included studies.

\begin{tabular}{|c|c|c|c|c|c|c|}
\hline Analysis & & Studies & Teeth & OIRR & $95 \% \mathrm{Cl}$ & PsG \\
\hline \multirow[t]{5}{*}{ Subgroup analysis } & Complete Treatment & 8 & 3078 & 1.11 & $0.80,1.42$ & 0.09 \\
\hline & No complete treatment & 7 & 434 & 0.49 & $0.23,0.75$ & \\
\hline & Extraction & 6 & 2252 & 0.81 & $0.32,1.30$ & 0.08 \\
\hline & Non-Extraction & 5 & 678 & 0.51 & $0.25,0.78$ & \\
\hline & & Studies & Teeth & Coeffient & $95 \% \mathrm{Cl}$ & $\mathbf{P}$ \\
\hline \multirow[t]{4}{*}{ Meta-regressions } & Male \% in sample & 13 & 3386 & -0.01 & $-0.03,0.02$ & 0.57 \\
\hline & Mean age in years & 11 & 3260 & 0.01 & $-0.07,0.08$ & 0.80 \\
\hline & Duration in months & 10 & 3106 & 0.03 & $0.00,0.06$ & 0.04 \\
\hline & & Studies & Teeth & OIRR & $95 \% \mathrm{Cl}$ & $P_{S G}$ \\
\hline \multirow[t]{7}{*}{ Sensitivity analysis } & Prospective & 6 & 560 & 0.59 & $0.20,0.97$ & 0.28 \\
\hline & Retrospective & 9 & 2952 & 0.99 & $0.68,1.30$ & \\
\hline & Voxel size $\leq 0.2 \mathrm{~mm}$ & 3 & 2106 & 1.15 & $0.45,1.85$ & 0.05 \\
\hline & Voxel size $>0.2 \mathrm{~mm}$ & 10 & 1134 & 0.64 & $0.37,0.91$ & \\
\hline & Root-level & 7 & 2756 & 1.05 & $0.66,1.44$ & 0.15 \\
\hline & Tooth-level & 8 & 756 & 0.62 & $0.34,0.91$ & \\
\hline & & Studies & Teeth & Coefficient & $95 \% \mathrm{Cl}$ & $\mathbf{P}$ \\
\hline Reporting biases & Egger's test & 15 & 3512 & -2.65 & $-7.59,2.29$ & 0.27 \\
\hline
\end{tabular}

$\mathrm{CI}$, confidence interval; OIRR, orthodontically induced root resorption; PsG, betweensubgroups $p$ value. 


\section{SUPPLEMENTARY MATERIAL}

Supplementary Table 1. List of databases searched with the corresponding strategies and hits (last search 24 January 2017).

\begin{tabular}{|c|c|c|c|c|}
\hline & Database & Search strategy used & Extend of search & Sum \\
\hline 1 & $\begin{array}{l}\text { MEDLINE (via Pubmed) } \\
\text { www.ncbi.nlm.nih.gov/pubmed }\end{array}$ & $\begin{array}{l}\text { ((((((("comput* tomograph*") OR "ct scan") OR "cbct") OR "cb ct") OR } \\
\text { "cone beam")) AND ((resorp*) OR resorb*)) AND ((((orthodont* }) \text { OR } \\
\text { tooth) OR teeth) OR root*) }\end{array}$ & In all fields & 644 \\
\hline 2 & $\begin{array}{l}\text { Cochrane Database of Systematic } \\
\text { Reviews } \\
\text { www.thecochranelibrary.com }\end{array}$ & 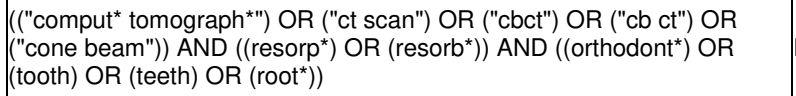 & In all fields & 41 \\
\hline 3 & $\begin{array}{l}\text { Google Scholar } \\
\text { www.scholar.google.com }\end{array}$ & $\begin{array}{l}\text { allintitle: root resorption "cone beam" OR "computed tomography" OR } \\
\text { "computed tomographic" OR "computerized tomography" OR } \\
\text { "computerised tomography" OR "ct scan" OR cbct OR "cb ct" OR tooth } \\
\text { OR teeth }\end{array}$ & All in title & 646 \\
\hline 4 & $\begin{array}{l}\text { ScienceDirect } \\
\text { www.sciencedirect.com }\end{array}$ & $\begin{array}{l}\text { TITLE-ABSTR-KEY(("comput* tomograph*" OR "ct scan" OR "cbct" OR } \\
\text { "cb ct" OR "cone beam")) and TITLE-ABSTR-KEY((resorp* OR resorb*) } \\
\left.\left.\text { AND (orthodont* OR tooth OR teeth OR root }{ }^{\star}\right)\right)\end{array}$ & $\begin{array}{l}\text { In title, abstract, keywords } \\
\text { [All Sources(Medicine and } \\
\text { Dentistry)] }\end{array}$ & 135 \\
\hline 5 & $\begin{array}{l}\text { Web of Science } \\
\text { https://apps.webofknowledge.com }\end{array}$ & $\begin{array}{l}\text { ("comput* tomograph*" OR "ct scan" OR "cbct" OR "cb ct" OR "cone } \\
\text { beam") AND TOPIC: (resorp* OR resorb*) AND TOPIC: (orthodont* OR } \\
\text { tooth OR teeth OR root*) } \\
\text { Refined by: RESEARCH AREAS: ( DENTISTRY ORAL SURGERY } \\
\text { MEDICINE OR RADIOLOGY NUCLEAR MEDICINE MEDICAL } \\
\text { IMAGING ) AND DOCUMENT TYPES: ( ARTICLE OR MEETING OR } \\
\text { REVIEW ) } \\
\text { Timespan: All years. } \\
\text { Search language=Auto }\end{array}$ & In the topic & 502 \\
\hline 6 & $\begin{array}{l}\text { Evidence-Based Medicine } \\
\text { www.ebm.bmj.com }\end{array}$ & $\begin{array}{l}\text { "comput* tomograph*" OR "ct scan" OR "cbct" OR "cb ct" OR } \\
\text { "cone beam" } \\
\text { resorb* OR resorp* } \\
\text { orthodont }{ }^{*} \text { OR tooth OR teeth OR root* All terms searched by } \\
\text { Text/Abstract/Title }\end{array}$ & In text, abstract, title & 58 \\
\hline 7 & $\begin{array}{l}\text { Scopus } \\
\text { www.scopus.com }\end{array}$ & $\begin{array}{l}\text { TITLE-ABS-KEY ( "comput* tomograph*" OR "ct scan" OR "cbct" OR "cb } \\
\text { ct" OR "cone beam" ) AND TITLE-ABS-KEY ( resorp* OR resorb* ) AND } \\
\text { TITLE-ABS-KEY ( orthodont* OR tooth OR teeth OR root* ) ) AND } \\
\text { ( LIMIT-TO ( DOCTYPE, "ar" ) OR LIMIT-TO ( DOCTYPE, "re" ) OR } \\
\text { LIMIT-TO ( DOCTYPE, "ip" ) OR LIMIT-TO ( DOCTYPE, "ch" ) OR } \\
\text { LIMIT-TO ( DOCTYPE, "cp" ) ) AND ( LIMIT- } \\
\text { TO ( SUBJAREA, "DENT" ) OR LIMIT-TO ( SUBJAREA, "MEDI" ) ) }\end{array}$ & In title, abstract, keywords & 759 \\
\hline 8 & $\begin{array}{l}\text { VHL Search Portal (Databases } \\
\text { included: LILACS, BBO, IBECS) } \\
\text { http://bvsalud.org }\end{array}$ & $\begin{array}{l}\text { (tw:("computed tomography" OR "computerised tomography" OR } \\
\text { "computerized tomography" OR "computed tomographic" OR "ct scan" } \\
\text { OR "cbct" OR "cb ct" OR "cone beam")) AND (tw:(resorp* OR resorb*)) } \\
\text { AND (tw:(orthodont* OR tooth OR teeth OR root*)) AND } \\
\text { (instance:"regional") AND ( db:("LILACS" OR "BBO" OR "IBECS")) }\end{array}$ & In title, abstract, subject & 61 \\
\hline 9 & $\begin{array}{l}\text { Ovid database } \\
\text { http://ovidsp.ovid.com }\end{array}$ & $\begin{array}{l}((\text { comput } \$ \text { tomograph } \$ \text { or ct scan or cbct or cb ct or cone beam) and } \\
(\text { resorp } \$ \text { or resorb } \$) \text { and (orthodont } \$ \text { or tooth or teeth or root } \$)) \text {.ab. }\end{array}$ & In abstract & 161 \\
\hline 10 & $\begin{array}{l}\text { Bandolier } \\
\text { http://medicine.ox.ac.uk/bandolier/ }\end{array}$ & $\begin{array}{l}\text { ("ct scan" or "computed tomography" or "computerised tomography" or } \\
\text { "computerized tomography" or "cbct" or "cb ct" or "cone beam") and } \\
\text { (resorption or resorbe) and ((orthodontic or orthodontics) or (tooth or } \\
\text { toothed or toothing) or (teeth or teethed or teething or teether or teethes) } \\
\text { or (root or rooted or rooting or rooter or roots)) }\end{array}$ & In all fields & 1 \\
\hline 11 & $\begin{array}{l}\text { African Journals Online } \\
\text { www.ajol.info }\end{array}$ & $\begin{array}{l}\text { ("comput* tomograph*" OR "ct scan" OR "cbct" OR "cb ct" OR "cone } \\
\text { beam") AND (resorp* OR resorb*) AND (orthodont* OR tooth OR teeth } \\
\text { OR root }{ }^{\star} \text { ) }\end{array}$ & In all fields & 0 \\
\hline 12 & $\begin{array}{l}\text { MetaRegister of Controlled Trials } \\
\text { www.controlled-trials.com }\end{array}$ & $\begin{array}{l}\text { 1. cone beam } \\
\text { 2. cbct } \\
\text { 3. cb-ct } \\
\text { 4. cb ct }\end{array}$ & In all fields & 23 \\
\hline 13 & $\begin{array}{l}\text { Digital dissertations (via UMI } \\
\text { Proquest) } \\
\text { http://search.proquest.com }\end{array}$ & $\begin{array}{l}\text { ("comput* tomograph*" OR "ct scan" OR "cbct" OR "cb ct" OR "cone } \\
\text { beam") AND (resorp* OR resorb*) AND (orthodont* OR tooth OR teeth } \\
\text { OR root*) }\end{array}$ & $\begin{array}{l}\text { In all fields } \\
\text { 1. Dissertations and Theses } \\
\text { 2. Conference Papers } \\
\text { 3. Proceedings } \\
\text { 4. Books } \\
\text { 5. Working Papers }\end{array}$ & 87 \\
\hline 14 & $\begin{array}{l}\text { German National Library of Medicine } \\
\text { http://www.medpilot.de }\end{array}$ & cone beam OR cbct OR cb ct & $\begin{array}{l}\text { In all fields } \\
\text { 1. Conference Proceedings } \\
\text { 2. Theses }\end{array}$ & 286 \\
\hline 15 & $\begin{array}{l}\text { Conference Paper Index (via } \\
\text { Conference Scientific Abstracts) } \\
\text { http://journals.cambridge.org }\end{array}$ & (cbct" OR "cb ct" OR "cone beam") AND (tooth OR teeth OR root*) & In all fields & 37 \\
\hline & Sum & & & 3441 \\
\hline
\end{tabular}


Supplementary Table 2. Eligibility criteria used for the study selection.

\begin{tabular}{|c|c|c|}
\hline Category & Inclusion criteria & Exclusion criteria \\
\hline \multirow[t]{7}{*}{$\begin{array}{l}\text { Participant } \\
\text { characteristics }\end{array}$} & $\begin{array}{l}\text { Studies on human participants of any } \\
\text { gender or malocclusion in the permanent } \\
\text { dentition with full development of the roots }\end{array}$ & $\begin{array}{l}\text { Patients with craniofacial syndromes, genetic } \\
\text { disorders, or cleft lip palate }\end{array}$ \\
\hline & & $\begin{array}{l}\text { Patients with temporomandibular joint } \\
\text { disorders }\end{array}$ \\
\hline & & $\begin{array}{l}\text { Clinical trials with inadequate sample size } \\
\text { groups, i.e studies with less than ten } \\
\text { participants }\end{array}$ \\
\hline & & $\begin{array}{l}\text { Clinical trials not reporting the size of the } \\
\text { examined sample/group }\end{array}$ \\
\hline & & $\begin{array}{l}\text { Clinical trials with patients in the deciduous or } \\
\text { mixed dentition stage }\end{array}$ \\
\hline & & $\begin{array}{l}\text { Clinical trials providing no information } \\
\text { regarding the developmental stage of the roots } \\
\text { of the teeth }\end{array}$ \\
\hline & & Animal studies \\
\hline Intervention & $\begin{array}{l}\text { Orthodontic treatment with fixed or } \\
\text { removable appliances in the permanent } \\
\text { dentition }\end{array}$ & $\begin{array}{l}\text { Orthodontic treatment with fixed or removable } \\
\text { appliances in the deciduous or mixed dentition }\end{array}$ \\
\hline Comparison & $\begin{array}{l}\text { Studies assessing root resorption before, } \\
\text { during, immediately following or after } \\
\text { orthodontic treatment with CBCT }\end{array}$ & $\begin{array}{l}\text { Studies assessing root resorption before, } \\
\text { during, immediately following or after } \\
\text { orthodontic treatment with the use of } 2 \\
\text { dimensional radiographic methods (periapical, } \\
\text { panoramic, lateral x-rays) }\end{array}$ \\
\hline Outcome & $\begin{array}{l}\text { Linear or volumetric measurements on } \\
\text { CBCTs }\end{array}$ & Any other outcome reported \\
\hline \begin{tabular}{|l} 
Principle \\
outcome \\
measures
\end{tabular} & $\begin{array}{l}\text { Studies providing linear or volumetric } \\
\text { measurements on CBCTs }\end{array}$ & $\begin{array}{l}\text { Studies providing linear measurements on } \\
\text { panoramic, cephalometric or periapical x rays }\end{array}$ \\
\hline \multirow[t]{15}{*}{ Study design } & Randomized controlled clinical trials & Unsupported opinion of expert \\
\hline & $\begin{array}{l}\text { Prospective controlled and uncontrolled } \\
\text { clinical trials }\end{array}$ & Editor's choices \\
\hline & $\begin{array}{l}\text { Retrospective controlled and uncontrolled } \\
\text { clinical trials }\end{array}$ & Replies to the author/editor \\
\hline & Retrospective cohort studies & Interviews \\
\hline & & Commentaries \\
\hline & & Observational studies \\
\hline & & Summaries \\
\hline & & Cross sectionals surveys \\
\hline & & Case series \\
\hline & & Case reports or reports of cases \\
\hline & & Case-control observational studies \\
\hline & & Books/Conferences abstracts \\
\hline & & Narrative reviews \\
\hline & & Systematic reviews \\
\hline & & Meta-analyses \\
\hline
\end{tabular}

CBCT, cone beam computerized tomography. 
Supplementary Table 3a. Summary of excluded studies at each phase.

\begin{tabular}{|l|l|}
\hline & Sum \\
\hline Initially retrieved articles & 2206 \\
\hline Exclusion by title & 1878 \\
\hline Exclusion by non-existing abstract & 2 \\
\hline Exclusion by abstract & 264 \\
\hline Exclusion by full text & 18 \\
\hline Full-texts that couldn't be retrieved & 6 \\
\hline Sum of excluded studies & 2168 \\
\hline
\end{tabular}


Supplementary Table 3b. List of articles excluded on basis of full-text from this study and reason for exclusion.

\begin{tabular}{|c|c|c|}
\hline $\mathrm{Nr}$ & Study & Reasons for exclusion \\
\hline 1 & $\begin{array}{l}\text { Fuhrmann R. Three-dimensional interpretation of periodontal lesions and remodeling during } \\
\text { orthodontic treatment. J Orofac Orthop 1996;57:224-37 }\end{array}$ & Case series \\
\hline 2 & $\begin{array}{l}\text { Fuhrmann R. Three-dimensional evaluation of periodontal remodeling during orthodontic } \\
\text { treatment. Semin Orthod 2002;8:23-8. }\end{array}$ & Case series \\
\hline 3 & $\begin{array}{l}\text { Chung CJ, Choi YJ, Kim KH. Approximation and contact of the maxillary central incisor } \\
\text { roots with the incisive canal after maximum retraction with temporary anchorage devices: } \\
\text { Report of } 2 \text { patients. Am J Orthod Dentofacial Orthop 2015;148:493-502. }\end{array}$ & Case series \\
\hline 4 & $\begin{array}{l}\text { Yu JH, Shu KW, Tsai MT, Hsu JT, Chang HW, Tung KL. A cone-beam computed } \\
\text { tomography study of orthodontic apical root resorption. J Dent Sci 2013;8:74-9. }\end{array}$ & Inadequate sample size \\
\hline 5 & $\begin{array}{l}\text { Wu J, Jiang J, Xu L, Liang C, Li C, Xu X. Alveolar bone thickness and root length changes } \\
\text { in the treatment of skeletal Class III patients facilitated by improved corticotomy: a cone- } \\
\text { beam CT analysis. Hua Xi Kou Qiang Yi Xue Za Zhi 2015;50:223-7. }\end{array}$ & $\begin{array}{l}\text { Initial CBCT was performed during } \\
\text { treatment and not before initiation } \\
\text { of treatment }\end{array}$ \\
\hline 6 & $\begin{array}{l}\text { Curado de Freitas J, Lyra O, Alencar A, Estrela C. Apical root resorption of maxillary first } \\
\text { molars related to headgear use as detected by cone beam computed tomography. } \\
\text { Stomatos } 2011 ; 33: 4-11 \text {. }\end{array}$ & No initial CBCT \\
\hline 7 & $\begin{array}{l}\text { Lund H. Cone Beam Computed Tomography in Evaluations of Some Side Effects of } \\
\text { Orthodontic Treatment. Master Thesis, Gothenburg, Sweden: University of Gothenburg, } \\
2011 .\end{array}$ & $\begin{array}{l}\text { Not linear or volumetric } \\
\text { measurements provided }\end{array}$ \\
\hline 8 & $\begin{array}{l}\text { Lund H, Gröndahl K, Gröndahl H-G. Cone beam computed tomography evaluations of } \\
\text { marginal alveolar bone before and after orthodontic treatment combined with premolar } \\
\text { extractions. Eur J Oral Sci 2012;120:201-11. }\end{array}$ & $\begin{array}{l}\text { Not linear or volumetric } \\
\text { measurements provided }\end{array}$ \\
\hline 9 & $\begin{array}{l}\text { Lund H, Gröndahl K, Hansen K, Gröndahl H-G. Apical root resorption during orthodontic } \\
\text { treatment. A prospective study using cone beam CT. Angle Orthod 2012:82:480-7. }\end{array}$ & $\begin{array}{l}\text { Not linear or volumetric } \\
\text { measurements provided }\end{array}$ \\
\hline 10 & $\begin{array}{l}\text { Makedonas D, Lund H, Hansen K. Root resorption diagnosed with cone beam computed } \\
\text { tomography after } 6 \text { months and at the end of orthodontic treatment with fixed appliances. } \\
\text { Angle Orthod } 2013 ; 83: 389-93 \text {. }\end{array}$ & $\begin{array}{l}\text { Not linear or volumetric } \\
\text { measurements provided }\end{array}$ \\
\hline 11 & $\begin{array}{l}\text { Makedonas D, Lund H, Gröndahl K, Hansen K. Root resorption diagnosed with cone beam } \\
\text { computed tomography after } 6 \text { months of orthodontic treatment with fixed appliance and the } \\
\text { relation to risk factors. Angle Orthod } 2012 ; 82: 196-201 \text {. }\end{array}$ & $\begin{array}{l}\text { Not linear or volumetric } \\
\text { measurements provided }\end{array}$ \\
\hline 12 & $\begin{array}{l}\text { Lund H, Gröndahl K, Gröndahl H-G. Cone Beam Computed Tomography for Assessment } \\
\text { of Root Length and Marginal Bone Level during Orthodontic Treatment. Angle Orthod } \\
\text { 2010;80:466-73. }\end{array}$ & $\begin{array}{l}\text { Not linear or volumetric } \\
\text { measurementsprovided }\end{array}$ \\
\hline 13 & $\begin{array}{l}\text { Kim SY, Lin SH, Gang SN, Kim HJ. Crown and root lengths of incisors, canines, and } \\
\text { premolars measured by cone-beam computed tomography in patients with malocclusions. } \\
\text { Korean J Orthod } 2013 ; 43: 271-8 \text {. }\end{array}$ & Observational study \\
\hline 14 & $\begin{array}{l}\text { Bie M, Moro A, Moresca R, Correr GM, Maris Losso E, Gomes R. Tomographic evaluation } \\
\text { of lower incisors after treatment using Herbst appliance. Orthod Sci Pract 2013;6:33-40. }\end{array}$ & Only bone measurements \\
\hline 15 & $\begin{array}{l}\text { Chung CJ, Choi YJ, Kim KH. Three-dimensional evaluation of mandibular changes } \\
\text { associated with Herbst treatment in growing Class-II patients. Master Thesis, Chapel Hill, } \\
\text { USA: University of North Carolina, } 2015 \text {. }\end{array}$ & Only bone measurements \\
\hline 16 & $\begin{array}{l}\text { Gunyuz-Toklu M, Germec-Cadan D, Tozlu M. Periodontal, dentoalveolar, } \\
\text { and skeletal effects of tooth-borne and tooth-bone-borne expansion appliances. Am J } \\
\text { Orthod Dentofacial Orthop 2015;148:97-109. }\end{array}$ & Only bone measurements \\
\hline 17 & $\begin{array}{l}\text { Yi J, Li M, Li Y, Li X, Zhao Z. Root resorption during orthodontic treatment with self-ligating } \\
\text { or conventional brackets: a systematic review and meta-analysis. BMC Oral Health } \\
2016 ; 16: 125 \text {. }\end{array}$ & Systematic Review \\
\hline 18 & $\begin{array}{l}\text { Yi J, Sun Y, Li Y, Li C, Li X, Zhao Z. Cone-beam computed tomography versus periapical } \\
\text { radiograph for diagnosing external root resorption: A systematic review and meta-analysis. } \\
\text { Angle Orthod 2017;87:328-37. }\end{array}$ & Systematic Review \\
\hline
\end{tabular}


Supplementary Table 3c. List of included studies

\begin{tabular}{|c|c|}
\hline Nr. & per \\
\hline 1 & $\begin{array}{l}\text { Abdel-Kader HM,Al-Khalefa HN, Ammar ASM. Maxillary canine root resorption concomitant to orthodontic } \\
\text { retraction: cone beam evaluation. International Journal of Clinical Dentistry 2016;9:29-46 }\end{array}$ \\
\hline 2 & $\begin{array}{l}\text { Ahn HW, Moon SC, Baek SH. Morphometric evaluation of changes in the alveolar bone and roots of the } \\
\text { maxillary anterior teeth before and after en masse retraction using cone-beam computed tomography. Angle } \\
\text { Orthod 2013;83:212-21. }\end{array}$ \\
\hline 3 & $\begin{array}{l}\text { Ajmera S, Venkatesh S, Ganeshkar SV. Volumetric evaluation of root resorption during orthodontic } \\
\text { treatment. J Clin Orhod 2014;48:113-9. }\end{array}$ \\
\hline 4 & $\begin{array}{l}\text { Alexander SP. Evaluation of three dimensional root surface changes and resorption following rapid maxillary } \\
\text { expansion: a cone-beam computed tomography investigation. Master Thesis, Houston, USA: University of } \\
\text { Texas, } 2014 \text {. }\end{array}$ \\
\hline 5 & $\begin{array}{l}\text { Alkyalcin S, Alexander SP, Silva RM, English JD. Evaluation of threedimensional root surface changes and } \\
\text { resorption following rapid maxillary expansion: a cone beam computed tomography investigation. Orthod } \\
\text { Craniofac Res } 2015 ; 18: 117-26 \text {. }\end{array}$ \\
\hline 6 & $\begin{array}{l}\text { Aras I, Tuncer AV. Comparison of anterior and posterior mini-implant-assisted maxillary incisor intrusion: } \\
\text { Root resorption and treatment efficiency. Angle Orthod } 2016 ; 86: 746-52 \text {. }\end{array}$ \\
\hline 7 & $\begin{array}{l}\text { Baysal A, Karadede I, Hekimoglu S, Ucar F, Ozer T, Veli I, Uysal T. Evaluation of root resorption following } \\
\text { rapid maxillary expansion using cone-beam computed tomography. Angle Orthod 2012;82:488-94. }\end{array}$ \\
\hline 8 & $\begin{array}{l}\text { Bolerjack BA, Harris EF. A CBCT Study of External Apical Root Resorption Contrasting Premolar-Extraction } \\
\text { and Non-Extraction Therapies. Master Thesis, Memphis, USA: University of Tennessee, } 2005 .\end{array}$ \\
\hline 9 & $\begin{array}{l}\text { Castro I, Valladares-Neto J, Estrela C.Contribution of cone beam computed tomography to the detection of } \\
\text { apical root resorption after orthodontic treatment in root-filled and vital teeth. Angle Orthod 2015;84:771-6. }\end{array}$ \\
\hline 10 & $\begin{array}{l}\text { Castro IO, Alencar AH, Valladares-Neto J, Estrela C. Apical root resorption due to orthodontic treatment } \\
\text { detected by cone beam computed tomography. Angle Orthod 2013;83:196-203. }\end{array}$ \\
\hline 11 & $\begin{array}{l}\text { Dindaroglou F, Dogan S. Evaluation and comparison of root resorption between tooth-borne and tooth- } \\
\text { tissue borne rapid maxillary expansion appliances: A CBCT study. Angle Orthod 2016;86:46-52. }\end{array}$ \\
\hline 12 & $\begin{array}{l}\text { Forst DD. External root resorption associated with maxillary expansion therapies as evaluated via cone } \\
\text { beam computed tomography: A retrospective randomized clinical trial. Master Thesis, Edmonton, Canada: } \\
\text { University of Alberta, } 2015 \text {. }\end{array}$ \\
\hline 13 & $\begin{array}{l}\text { Guo Y, He S, Gu T, Liu Y, Chen S. Genetic and clinical risk factors of root resorption associated } \\
\text { with orthodontic treatment.Am J Orthod Dentofacial Orthop 2016;150:283-9. }\end{array}$ \\
\hline 14 & $\begin{array}{l}\text { Harris LM. Cone-beam computed tomography evaluation of the morphology and resorption of premolar and } \\
\text { molar roots in response to rapid maxillary expansion. Master Thesis, Houston, USA: University of Texas, } \\
2015 \text {. }\end{array}$ \\
\hline 15 & $\begin{array}{l}\text { Johnson, SE. Analysis of posterior root resorption utilizing cone-beam computed tomography: suresmle Vs } \\
\text { conventional edgwise techniques. Master Thesis, Oklahoma City, USA: University of Oklahoma, } 2010 .\end{array}$ \\
\hline 16 & $\begin{array}{l}\text { Kau C. A radiographic analysis of tooth morphology following the use of a novel cyclical force device in } \\
\text { orthodontics. Head Face Med } 2011 ; 7: 14 \text {. }\end{array}$ \\
\hline 17 & $\begin{array}{l}\text { Kaylar E, Schauseil M, Kuvat SV, Emekli U, Firatli U. Comparison of tooth-borne and hybrid devices in } \\
\text { surgically assisted rapid maxillary expansion: A randomized clinical cone-beam computed tomography } \\
\text { study. J Craniomaxillofac Surg 2016;44:285-93. }\end{array}$ \\
\hline 18 & $\begin{array}{l}\text { Leite V, Conti AC, Navarro R, Almeida M, Oltramari-Navarro P, Almeida R. Comparison of root resorption } \\
\text { between self-ligating and conventional preadjusted brackets using cone beam computed tomography. Angle } \\
\text { Orthod 2012;82:1078-82. }\end{array}$ \\
\hline 19 & $\begin{array}{l}\text { Li W, Chen F, Feng Z, Ding W, Ye Q, Shi J, Fu B. Volumetric measurement of root resorption following } \\
\text { molar mini-screw implant intrusion using cone beam computed tomography. PLoS One 2013;8:e60962. }\end{array}$ \\
\hline 20 & $\begin{array}{l}\text { Liu Y, Guo H. Comparison of root resorption between self-ligating and conventional brackets using cone- } \\
\text { beam CT. Shanghai J Stomatol } 2016 ; 25: 238-41 \text {. }\end{array}$ \\
\hline 21 & $\begin{array}{l}\text { Lombardo L, Bragazzi R, Perissinotto C, Mirabella D, Siciliani G. Cone-beam computed tomography } \\
\text { evaluation of periodontal and bone support loss in extraction cases. Prog Orthod 2013;11:29. }\end{array}$ \\
\hline 22 & $\begin{array}{l}\text { Lynch JR. Three-dimensional evaluation of the effect of maxillary incisor retraction on the palatal bone and } \\
\text { root resorption. Master Thesis, Farmington, USA: University of Connecticut, } 2011 .\end{array}$ \\
\hline 23 & $\begin{array}{l}\text { Ma Q, Wang T, Wu T, Liu S, Li H. Evaluation of root resorption after palatal expansion by magnetic } \\
\text { expansion appliance. Hua Xi Kou Qiang Yi Xue Za Zhi 2013;31:600-4. }\end{array}$ \\
\hline 24 & $\begin{array}{l}\text { Nakada T, Motoyoshi M, Horinuki E, Shimizu N. Cone-beam computed tomography evaluation of the } \\
\text { association of cortical plate proximity and apical root resorption after orthodontic treatment. J Oral Sci } \\
2016 ; 58: 231-6 \text {. }\end{array}$ \\
\hline
\end{tabular}




\begin{tabular}{|c|l|}
\hline 25 & $\begin{array}{l}\text { Nimeri G, Kau C, Corona R, Shelly J. The effect of photobiomodulation on root resorption during orthodontic } \\
\text { treatment. Clin Cosmet Investig Dent 2014;15:1-8. }\end{array}$ \\
\hline 26 & $\begin{array}{l}\text { Oliveira TMF, Claudino LV, Mattos CT, Sant'Anna EF. Maxillary dentoalveolar assessment following } \\
\text { retraction of maxillary incisors: a preliminary study. Dental Press J Orthod 2016;21:82-9. }\end{array}$ \\
\hline 27 & $\begin{array}{l}\text { Oliveira TMF. Evaluation of dentoalveolar structure before and after retraction of the upper incisors with } \\
\text { cone beam computed tomography. Master Thesis, Rio de Janeiro, Brazil: Federal University of Rio de } \\
\text { Janeiro, 2011. }\end{array}$ \\
\hline 28 & $\begin{array}{l}\text { Patel S, Dawood A, Wilson R, Horner K, Mannocci F. The detection and management of root resorption } \\
\text { lesions using intraoral radiography and cone beam computed tomography-an in vivo investigation. Int } \\
\text { Endod J 2009;42:831-8. }\end{array}$ \\
\hline 29 & $\begin{array}{l}\text { Schwarz JP, Raveli TB, Almeida KC, Schwarz-Filho HO, Raveli DB.Cone beam computed tomography } \\
\text { study of apical root resorption induced by Herbst appliance. J Appl Oral Sci 2015;23:479-85. }\end{array}$ \\
\hline 30 & $\begin{array}{l}\text { Wang B, Shen G, Fang B, Yu H, Wu Y. Augmented corticotomy-assisted presurgical orthodontics of Class } \\
\text { III malocclusions: A cephalometric and cone-beam computed tomography study. J Craniofac Surg } \\
\text { 2013;24:1886-90. }\end{array}$ \\
\hline 31 & $\begin{array}{l}\text { Wang F, Wang J, Zhang X. Examining incisor root resorption using CBCT after orthodontic treatment for } \\
\text { adults with skeletal class III malocclusion. Tianjin Med J 2015;43:390-3. }\end{array}$ \\
\hline 32 & $\begin{array}{l}\text { Wen F, Chen G, Liu Y. Morphological analysis of roots and alveolar bone changes after upper anterior } \\
\text { retraction with maximum anchorage based on cone-beam computed tomography. Beijing Da Xue Xue Bao } \\
\text { Yi Xue Ban 2016;48:702-8. }\end{array}$ \\
\hline 33 & $\begin{array}{l}\text { Yang Xue, Qian Y.Torque control evaluated by lateral cephalometric radiography and cone-beam CT after } \\
\text { retraction of the upper anterior teeth. Shanghai J Stomatol 2016;25:469-74. }\end{array}$ \\
\hline
\end{tabular}


Supplementary Table 4. Communication attempts with corresponding authors of identified studies.

\begin{tabular}{|c|l|l|}
\hline Nr. & Paper & Status \\
\hline 1 & $\begin{array}{l}\text { Cassarella DW. CBCT assessment of root resorption: the impact of incisor } \\
\text { position and direction of movement on external apical root resorption during } \\
\text { orthodontic treatment. Master Thesis, Los Angeles, USA: University of } \\
\text { California Los Angeles, 2011. }\end{array}$ & $\begin{array}{l}\text { Corresponding author } \\
\text { contacted; response } \\
\text { pending. }\end{array}$ \\
\hline 2 & $\begin{array}{l}\text { Chang, JSM. Examining external apical root resorption in relation to alveolar } \\
\text { bone anatomy and tooth movement using come beam volumetric } \\
\text { tomography. Master Thesis, Los Angeles, USA: University of California Los } \\
\text { Angeles, 2008. }\end{array}$ & Author contacted; response \\
\hline 3 & $\begin{array}{l}\text { Chaves M, Chaves-Netto H, Maciel S, Carvalho F. M. Radiographic } \\
\text { evaluation of the root resorption in teeth under orthodontic treatment. }\end{array}$ & $\begin{array}{l}\text { Author contacted; response } \\
\text { pending. }\end{array}$ \\
\hline 4 & $\begin{array}{l}\text { Martel D. External apical root resorption and fixed orthodontic tooth } \\
\text { movement. Int J Orthod Milwaukee 2009;20:39-40. }\end{array}$ & $\begin{array}{l}\text { Author contacted; response } \\
\text { pending. }\end{array}$ \\
\hline 5 & $\begin{array}{l}\text { Sun B, Wang L, Deng R, Ding Y. Comparative evaluation of root resorption } \\
\text { in mandibular incisors following the treatment of adults with skeletal class III. } \\
\text { Progress in Modern Biomedicine 2012;6. }\end{array}$ & $\begin{array}{l}\text { Author contacted; response } \\
\text { pending. }\end{array}$ \\
\hline 6 & $\begin{array}{l}\text { Wu E. Orthodontically induced external apical root resorption, assessed with } \\
\text { high-resolution CBCT. Master Thesis, Los Angeles, USA: University of of } \\
\text { California Los Angeles, 2010. }\end{array}$ & $\begin{array}{l}\text { Author contacted; response } \\
\text { pending. }\end{array}$ \\
\hline
\end{tabular}


Supplementary Table 5. Characteristics of included studies regarding outcomes measured.

\begin{tabular}{|c|c|c|c|c|c|c|}
\hline i & & & & & & \\
\hline Study & $\begin{array}{l}\text { leeth } \\
\text { studied }\end{array}$ & Sum & Outcomes & Time of measurements & TxDur & Exposure parameters \\
\hline Abdel-Kader 2016 & (2) 13,23 & 32 & Tooth-L/S & $\begin{array}{l}\text { T1: Pre-Tx } \\
\text { T2: Post C Retr. }\end{array}$ & $6.3 \mathrm{mos}$ & $\begin{array}{l}12 \mathrm{~mA} ; 90 \mathrm{kV} ; 12 \mathrm{sec} ; \text { Vox } \\
0.2 \mathrm{~mm} ; \mathrm{FOV} 5 \mathrm{x} 8 \mathrm{~cm}\end{array}$ \\
\hline Ahn 2013 & (6) $M \times 3-3$ & 204 & Root-L/S & $\begin{array}{l}\text { T1: Pre-Tx } \\
\text { T2: Post-space closure }\end{array}$ & $21.7 \mathrm{mos}$ & $\begin{array}{l}\text { 4.0mA; 90kVp; } 24 \mathrm{~s} ; \text { Vox } \\
0.2 \mathrm{~mm} ; \text { FOV } 12 \times 9 \mathrm{~cm}\end{array}$ \\
\hline Ajmera 2014 & (6) $M \times 3-3$ & 288 & Root-V/S & $\begin{array}{l}\text { T1: Pre-Tx } \\
\text { T2: Post-space closure }\end{array}$ & NR & $\begin{array}{l}\text { 10mA; 70kVp; 10.8s; Vox } \\
\text { NR; FOV NR }\end{array}$ \\
\hline $\begin{array}{l}\text { Alexander 2014; } \\
\text { Akyalcin } 2015\end{array}$ & (4) Mx 4,6 & 96 & $\begin{array}{l}\text { Tooth-L/S } \\
\text { Root-V }\end{array}$ & $\begin{array}{l}\text { T1: Pre-Tx } \\
\text { T2: In Ret }\end{array}$ & $4.8 \mathrm{mos}$ & $\begin{array}{l}\text { 4.0mA; 85kVp; 8.0s; Vox } \\
0.18 \mathrm{~mm} ; \text { FOV 8x8cm }\end{array}$ \\
\hline Aras 2016 & (4) Mx 2-2 & 124 & $\begin{array}{l}\text { Root-L } \\
\text { Root-V }\end{array}$ & $\begin{array}{l}\text { T1: Pre-Tx } \\
\text { T2: During Tx }\end{array}$ & $4.0 \mathrm{mos}$ & $\begin{array}{l}10 \mathrm{~mA} ; 90 \mathrm{kVp} ; \mathrm{Vox} 0.3 \mathrm{~mm} ; \\
\mathrm{NR}\end{array}$ \\
\hline Baysal 2012 & (6) Mx 4-6 & 227 & Root-V & $\begin{array}{l}\text { T1: Pre-Tx } \\
\text { T2: Post RME }\end{array}$ & NR & $\begin{array}{l}\text { 5.0mA; } 120 \mathrm{kV} ; 9.6 \mathrm{~s} ; \mathrm{Vox} \\
\text { 0.3mm; FOV NR }\end{array}$ \\
\hline Bolerjack 2005 & $\begin{array}{l}\text { (3) } 11,12, \\
16\end{array}$ & 285 & $\begin{array}{l}\text { Root-L } \\
\text { Tooth-L }\end{array}$ & $\begin{array}{l}\text { T1: Pre-Tx } \\
\text { T2: Post-Tx }\end{array}$ & $26.4 \mathrm{mos}$ & $\begin{array}{l}\text { 4.5mA; } 120 \mathrm{kVp} ; \mathrm{NR} ; \mathrm{Vox} \\
\text { 0.4mm; FOV NR }\end{array}$ \\
\hline $\begin{array}{l}\text { Castro 2013; } \\
\text { Castro 2015 }\end{array}$ & $\begin{array}{l}\text { (28) } \mathrm{Mx} / \mathrm{Md} \\
7-7\end{array}$ & 1256 & Tooth-L & $\begin{array}{l}\text { T1: Pre-Tx } \\
\text { T2: Post-Tx }\end{array}$ & $22.0 \mathrm{mos}$ & $\begin{array}{l}\text { 3.8mA; } 120 \mathrm{kVp} ; 40 \mathrm{~s} ; \text { Vox } \\
0.25 \mathrm{~mm} ; \text { FOV } 13 \mathrm{~cm}\end{array}$ \\
\hline Dindaroglu 2016 & (6) Mx 4-6 & 198 & Tooth-V & $\begin{array}{l}\text { T1: Pre-Tx } \\
\text { T2: Post-RME } \\
\text { T3: In Ret } \\
\end{array}$ & $6.0 \mathrm{mos}$ & $\begin{array}{l}70 \mathrm{kVp}, 10 \mathrm{~mA}, 10.8 \mathrm{~s} ; \mathrm{Vox} \\
0.2 \mathrm{~mm}\end{array}$ \\
\hline Forst 2015 & (1) $16 / 26$ & 52 & Tooth-V & $\begin{array}{l}\text { T1: Pre-Tx } \\
\text { T2: In Ret }\end{array}$ & $12.0 \operatorname{mos}^{\$}$ & $\begin{array}{l}\text { 6.2mA; } 110 \mathrm{kVp} ; \mathrm{NR} ; \mathrm{Vox} \\
\text { 0.25mm; FOV NR }\end{array}$ \\
\hline Guo 2016 & (1) 21 & 174 & Tooth-V & $\begin{array}{l}\text { T1: Pre-Tx } \\
\text { T2: Post-Tx }\end{array}$ & $20.6 \mathrm{mos}$ & NR \\
\hline Harris 2015 & (2) $M x 4,6$ & $40 \dagger$ & Tooth-L & $\begin{array}{l}\text { T1: Pre-Tx } \\
\text { T2: In Ret }\end{array}$ & $3.0 \operatorname{mos}^{\$}$ & $\begin{array}{l}10 \mathrm{~mA} ; 70 \mathrm{kVp} ; 32.5 \mathrm{sec} ; \mathrm{Vox} \\
0.4 \mathrm{~mm}\end{array}$ \\
\hline Johnson 2010 & \begin{tabular}{|l|}
$(8) \mathrm{Mx} / \mathrm{Md}$ \\
4,6
\end{tabular} & 302 & Tooth-L & $\begin{array}{l}\text { T1: Pre-Tx } \\
\text { T2: Post-Tx (max 3mos) }\end{array}$ & $\begin{array}{l}\text { Gp1: } 19.5 \text { mos } \\
\text { Gp2: } 13.9 \text { mos }\end{array}$ & Vox $0.3-0.42 \mathrm{~mm}$ \\
\hline Kau 2011 & $\begin{array}{l}\text { (24) } \mathrm{Mx} / \mathrm{Md} \\
6-6\end{array}$ & 325 & Root-L & $\begin{array}{l}\text { T1: Pre-Tx } \\
\text { T2: In Tx }\end{array}$ & $6.0 \mathrm{mos}$ & $\begin{array}{l}\text { 14s; Vox 0.15-0.30mm; } \\
\text { FOV } 15 \mathrm{~cm}\end{array}$ \\
\hline Kaylar 2016 & (2) $M x 4,6$ & 40 & Tooth-L & $\begin{array}{l}\text { T1: Pre-Tx } \\
\text { T3: Post-RME } \\
\text { T2: In Ret }\end{array}$ & $6.0 \mathrm{mos}^{\$}$ & $\begin{array}{l}\text { 12.5mA; 90kVp; NR; Vox } \\
0.25 \mathrm{~mm} ; \mathrm{FOV} 14.5 \mathrm{~cm}\end{array}$ \\
\hline Leite 2012 & $\begin{array}{l}\text { (8) Mx/Md } \\
2-2\end{array}$ & 152 & Tooth-L & $\begin{array}{l}\text { T1: Pre-Tx } \\
\text { T2: In Tx }\end{array}$ & $6.0 \mathrm{mos}$ & $\begin{array}{l}36 \mathrm{~mA} ; 120 \mathrm{kVp} ; 40 \mathrm{~s} ; \text { Vox } \\
0.4 \mathrm{~mm}\end{array}$ \\
\hline Li 2013 & (2) Mx 6 & 12 & Root-V & $\begin{array}{l}\text { T1: Pre-Tx } \\
\text { T2: Post-Intr }\end{array}$ & $6.0 \mathrm{mos}$ & $\begin{array}{l}15 \mathrm{~mA} ; 110 \mathrm{kVp} ; 36 \mathrm{~s} ; \mathrm{Vox} \\
0.2-0.4 \mathrm{~mm}\end{array}$ \\
\hline Liu 2016 & (4) Mx 2-2 & 200 & Tooth-L & $\begin{array}{l}\text { T1: Pre-Tx } \\
\text { T2: Post-Tx }\end{array}$ & NR & NR \\
\hline Lombardo 2013 & $\begin{array}{l}\text { (8) Mx/Md } \\
2-2\end{array}$ & 176 & Root-L & $\begin{array}{l}\text { T1: Pre-Tx } \\
\text { T2: Post-Tx }\end{array}$ & 20.5 mos & $\begin{array}{l}\text { 1.0-2.0mA; } 110 \mathrm{kVp} ; 5.4 \mathrm{~s} ; \\
\text { NR }\end{array}$ \\
\hline Lynch 2011 & (2) 11,21 & 244 & Tooth-L & $\begin{array}{l}\text { T1: Pre-Tx } \\
\text { T2: Post-Tx }\end{array}$ & $21.8 \mathrm{mos}$ & $\begin{array}{l}\text { 23.9mA; 120kVp; 20s; Vox } \\
0.3 \mathrm{~mm} ; \text { FOV } 13 \times 16 \mathrm{~cm}\end{array}$ \\
\hline Ma 2013 & (6) Mx 4-6 & 190 & Root-L & $\begin{array}{l}\text { T1: Pre-Tx } \\
\text { T2: Post-RME }\end{array}$ & $9.3 \mathrm{mos}$ & $\begin{array}{l}23 \mathrm{~mA} ; 110 \mathrm{kVp} ; 3.6 \mathrm{~s} ; \mathrm{Vox} \\
0.25 \mathrm{~mm}\end{array}$ \\
\hline Nakada 2016 & (2) 11,21 & 60 & Root-L & $\begin{array}{l}\text { T1: Pre-Tx } \\
\text { T2: Post-retraction }\end{array}$ & NR & $\begin{array}{l}\text { 7.0mA; 90kVp; NR; Vox } \\
0.125 \mathrm{~mm} \text {; FOV NR }\end{array}$ \\
\hline Nimeri 2014 & $\begin{array}{l}(24) \mathrm{Mx} / \mathrm{Md} \\
6-6\end{array}$ & 480 & Tooth-L & $\begin{array}{l}\text { T1: Pre-Tx } \\
\text { T2: Post-alignment or space } \\
\text { closure }\end{array}$ & NR & Vox $0.3 \mathrm{~mm}$; FOV $18 \times 25 \mathrm{~cm}$ \\
\hline Patel 2012 & $\begin{array}{l}\text { (8) Mx/Md } \\
2-2\end{array}$ & 493 & Tooth-L & $\begin{array}{l}\text { T1: Pre-Tx } \\
\text { T2: Post-Tx (max 3mos) }\end{array}$ & $\begin{array}{l}\text { Gp1: } 18.1 \mathrm{mos} \\
\text { Gp2: } 14.2 \mathrm{mos}\end{array}$ & Vox $0.3-0.42 \mathrm{~mm}$ \\
\hline Schwarz 2015 & $\begin{array}{l}(28) \mathrm{Mx} / \mathrm{Md} \\
7-7\end{array}$ & 980 & Tooth-L & $\begin{array}{l}\text { T1: Pre-Tx } \\
\text { T2: Post- Herbst Tx }\end{array}$ & $8.5 \mathrm{mos}$ & $\begin{array}{l}\text { 18.5mA; } 120 \mathrm{kVp} ; \mathrm{NR} ; \mathrm{Vox} \\
0.4 \mathrm{~mm} ; \text { FOV } 17 x 13.3 \mathrm{~cm}\end{array}$ \\
\hline $\begin{array}{l}\text { Oliveira 2011; } \\
\text { Oliveira 2016 } \\
\end{array}$ & (4) $M \times 2-2$ & 44 & Tooth-L & $\begin{array}{l}\text { T1: Pre-Tx } \\
\text { T2: } 1 \text { mo post-space closure }\end{array}$ & NR & $\begin{array}{l}5 \mathrm{~mA} ; 120 \mathrm{kVp} ; 20 \mathrm{~s} ; \text { Vox } \\
0.4 \mathrm{~mm} ; \text { FOV } 13 \times 17 \mathrm{~cm}\end{array}$ \\
\hline Wang 2013 & (1) 31 & 56 & Root-L & $\begin{array}{l}\text { T1: Pre-Tx } \\
\text { T2: Post-decompensation }\end{array}$ & $\begin{array}{l}\text { Gp1: } 13.3 \text { mos } \\
\text { Gp2: } 7.8 \text { mos }\end{array}$ & NR \\
\hline Wang 2015 & $\begin{array}{l}\text { (8) } M x / M d \\
2-2\end{array}$ & 240 & Root -V & $\begin{array}{l}\text { T1: Pre-Tx } \\
\text { T2: Post-decompensation }\end{array}$ & $8.7 \mathrm{mos}$ & $\begin{array}{l}\text { 60mA; 90kVp; } 24 \mathrm{~s} ; \text { Vox 0.1- } \\
0.3 \mathrm{~mm}\end{array}$ \\
\hline Wen 2016 & (6) $M \times 3-3$ & 72 & Root-L & $\begin{array}{l}\text { T1: Pre-Tx } \\
\text { T2: Post-Tx }\end{array}$ & $30.0 \mathrm{mos}$ & $\begin{array}{l}7.0 \mathrm{~mA} ; 90 \mathrm{kVp} ; 15 \mathrm{~s} ; \mathrm{NR} \\
20 \times 19 \mathrm{~cm}\end{array}$ \\
\hline
\end{tabular}




\begin{tabular}{|l|l|l|l|l|l|l|}
\hline Yang 2016 & (6) Mx 3-3 & 42 & Tooth-L & $\begin{array}{l}\text { T1: Pre-Tx } \\
\text { T2: Post-retraction }\end{array}$ & NR & NR; NR; Vox 0.25mm; NR \\
\hline
\end{tabular}

$£$ for both groups

*randomization was performed for another study, not on the basis of root resorption

$\$$ period including a retention period about 12 mos

$\dagger$ Right and left teeth of the same category were averaged for analyses.

TxDur, treatment duration; Mx, maxilla; Md, mandible; L, length; S, surface; V, volume; Tx, treatment; C, canine; Retr, retraction; Ret, retention; RME, rapid maxillary expansion; Intr, intrusion; max, maximum; mos, months; Vox, voxel size; FOV, field of view; NR, not reported. 
Table 6a. Risk of bias assessment of identified non-randomized studies.

\begin{tabular}{|c|c|c|c|c|c|c|c|c|c|c|c|c|c|c|c|c|c|c|c|c|c|c|c|c|c|c|c|}
\hline \multirow[b]{2}{*}{ Studies } & \multicolumn{10}{|c|}{ Reporting quality } & \multicolumn{3}{|c|}{\begin{tabular}{|l|} 
External \\
validity
\end{tabular}} & \multicolumn{7}{|c|}{ Internal validity-bias } & \multicolumn{6}{|c|}{$\begin{array}{l}\text { Internal validity- } \\
\text { confounding }\end{array}$} & \multirow{2}{*}{\begin{tabular}{|c|} 
Power \\
27 \\
\end{tabular}} \\
\hline & 1 & & & 4 & 5 & & & & & 10 & & & & & & & & & 19 & & & & & 24 & 25 & & \\
\hline Abdel-Kader 2016 & - & 1 & 1 & 1 & - & & & & & - & - & - & 1 & - & - & - & - & 1 & 1 & 1 & - & - & - & - & - & 1 & $4 / 5$ \\
\hline Ahn 2013 & 1 & 1 & 1 & 1 & - & 1 & & & & 1 & - & - & - & - & - & 1 & 1 & 1 & - & 1 & - & - & - & - & - & 1 & $5 / 5$ \\
\hline Ajmera 2014 & 1 & 1 & 1 & 1 & - & 1 & & & & - & 1 & - & 1 & - & - & 1 & - & 1 & - & 1 & - & - & - & - & - & 1 & $5 / 5$ \\
\hline $\begin{array}{l}\text { Alexander 2014; } \\
\text { Akyalcin } 2015\end{array}$ & 1 & 1 & 1 & 1 & - & 1 & 1 & - & 1 & 1 & - & - & - & - & - & 1 & 1 & 1 & - & 1 & - & - & - & - & - & 1 & $5 / 5$ \\
\hline Baysal 2012 & 1 & 1 & - & 1 & - & 4 & 1 & - & 1 & 1 & - & - & 1 & - & - & 1 & - & 1 & - & 1 & - & - & - & - & - & - & $5 / 5$ \\
\hline Bolerjack 2005 & 1 & 1 & 1 & 1 & 1 & 1 & 1 & 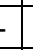 & 1 & 1 & - & - & - & - & - & 1 & 1 & 1 & - & 1 & - & - & - & - & - & - & $5 / 5$ \\
\hline $\begin{array}{l}\text { Castro 2013; Castro } \\
2015\end{array}$ & 1 & 1 & 1 & 1 & - & 1 & 1 & - & 1 & 1 & - & - & - & - & - & 1 & - & 1 & - & 1 & - & - & - & - & - & 1 & $5 / 5$ \\
\hline Guo 2016 & 1 & 1 & 1 & 1 & - & 1 & 1 & - & 1 & 1 & 1 & 1 & 1 & - & - & - & - & 1 & - & 1 & 1 & 1 & - & - & - & 1 & $5 / 5$ \\
\hline Harris 2015 & 1 & 1 & 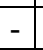 & 1 & 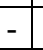 & 1 & 1 & - & 1 & 1 & & - & 1 & - & 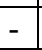 & - & - & 1 & - & 1 & 1 & - & 1 & - & - & 1 & $5 / 5$ \\
\hline \begin{tabular}{|l|}
$J o h n s o n$ \\
2010
\end{tabular} & 1 & 1 & 1 & 1 & 1 & 1 & 1 & - & 1 & 1 & - & - & - & - & 1 & 1 & 1 & 1 & - & 1 & - & 1 & -1 & - & - & 1 & $5 / 5$ \\
\hline Kau 2011 & 1 & 1 & 1 & - & - & 1 & 1 & - & - & - & - & - & - & - & - & 1 & 1 & 1 & - & - & - & - & - & - & - & - & $3 / 5$ \\
\hline Li 2013 & 1 & 1 & - & 1 & - & 1 & 1 & - & - & - & - & - & 1 & - & - & 1 & - & 1 & - & 1 & - & - & - & - & - & 1 & $2 / 5$ \\
\hline Lombardo 2013 & 1 & 7 & 1 & - & 1 & 1 & - & - & 1 & - & - & - & - & - & - & 1 & 1 & 1 & - & 1 & - & - & - & - & - & 1 & $1 / 5$ \\
\hline Lynch 2011 & 1 & 1 & 1 & 1 & 1 & 1 & 1 & - & & 1 & - & - & - & - & - & 1 & 1 & 1 & - & 1 & - & - & - & - & - & 1 & $5 / 5$ \\
\hline Nakada 2016 & 1 & 1 & 1 & 1 & - & 4 & 1 & 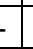 & 1 & - & - & - & - & - & - & 1 & 1 & 1 & - & 1 & - & - & - & - & - & 1 & $5 / 5$ \\
\hline Nimeri 2014 & 1 & 1 & 1 & 1 & - & 1 & 1 & - & 1 & 1 & - & - & - & - & - & 1 & - & 1 & - & 1 & - & - & - & - & - & 1 & $5 / 5$ \\
\hline Patel 2012 & 1 & 1 & 1 & 1 & - & 1 & 1 & & 1 & 1 & - & - & - & - & 1 & 1 & 1 & 1 & - & 1 & - & 1 & - & - & - & 1 & $5 / 5$ \\
\hline Qiaoling 2013 & 1 & 1 & 1 & 1 & - & 1 & 1 & 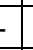 & 1 & 1 & - & - & 1 & - & - & 1 & 1 & 1 & - & 1 & 1 & 1 & - & - & - & 1 & $4 / 5$ \\
\hline Schwarz 2015 & 1 & 1 & 1 & 1 & - & 4 & 1 & 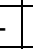 & & 1 & - & - & - & - & - & 1 & 1 & 1 & - & 1 & - & - & - & - & - & 1 & $5 / 5$ \\
\hline $\begin{array}{l}\text { Tiago 2011; Oliveira } \\
2016\end{array}$ & 1 & 1 & 1 & 1 & - & 1 & 1 & - & & 1 & 1 & - & 1 & - & - & 1 & - & 1 & - & 1 & - & - & - & - & - & 1 & $1 / 5$ \\
\hline Wang 2013 & 1 & 1 & 1 & 1 & 1 & 1 & 1 & & & 1 & 1 & - & 1 & - & - & 1 & 1 & 1 & - & 1 & 1 & \begin{tabular}{|l|}
1 \\
\end{tabular} & - & - & - & 1 & $5 / 5$ \\
\hline Wang 2015 & 1 & 1 & 1 & 1 & - & 1 & 1 & & 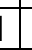 & - & - & 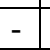 & 1 & - & - & - & - & 1 & - & 1 & -1 & - & - & - & - & 1 & $5 / 5$ \\
\hline Wen 2016 & 1 & 1 & 1 & 1 & - & 1 & 1 & & & 1 & 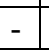 & - & 1 & - & - & 1 & - & 1 & - & 1 & 1 & 1 & - & - & - & 1 & $1 / 5$ \\
\hline Yang 2016 & 1 & & 1 & 1 & - & 1 & 1 & - & 1 & 1 & - & 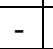 & 1 & - & - & 1 & - & 1 & & 1 & 1 & - & - & - & - & 1 & $0 / 5$ \\
\hline
\end{tabular}


Table 7. Within-study comparisons from identified randomized clinical trials

\begin{tabular}{|c|c|c|c|c|c|c|c|c|c|c|c|}
\hline $\mathrm{Tx}$ & $\begin{array}{l}\text { Outcom } \\
\text { e }\end{array}$ & Scope & Referent & Experimental & $\begin{array}{l}\text { Trial } \\
\mathrm{s}\end{array}$ & MD & $95 \% \mathrm{Cl}$ & $\mathrm{P}$ & $l^{2}(95 \% \mathrm{Cl})$ & $\begin{array}{l}\text { tau }^{2} \\
(95 \% \\
\text { Cl) }\end{array}$ & $\begin{array}{l}95 \% \\
\text { Prl }\end{array}$ \\
\hline Fixed appliance & Linear & Fixed appliance Tx & $\begin{array}{l}\text { Conventional } \\
\text { brackets }\end{array}$ & Self-ligating brackets & 2 & 0.03 & $-0.20,0.26$ & 0.80 & $\begin{array}{l}0 \% \\
(0 \%, 96 \%)\end{array}$ & $\begin{array}{l}0 \\
(0,0.78)\end{array}$ & - \\
\hline Fixed appliance & Linear & Anterior intrusion & Posterior TADs & Anterior TADs & 1 & 0.34 & $0.20,0.48$ & $<0.001$ & - & - & - \\
\hline Fixed appliance & Volume & Anterior intrusion & Posterior TADs & Anterior TADs & 1 & 6.32 & $2.35,10.29$ & 0.002 & - & - & - \\
\hline RME & Linear & RME & Hyrax & Hybrid-Hyrax (TADs) & 1 & 0.07 & $-0.12,0.26$ & 0.48 & - & - & - \\
\hline RME & Volume & RME & Hyrax & Hybrid-Hyrax (TADs) & 1 & -17.82 & $-47.51,11.87$ & 0.24 & - & - & - \\
\hline RME & Volume & RME & Hyrax & Haas & 1 & -10.94 & $-18.64,-3.24$ & 0.005 & - & - & - \\
\hline
\end{tabular}

$\mathrm{Cl}$, confidence interval; MD, mean difference; Prl, predictive interval; RME, rapid maxillary expansion; TAD, temporary anchorage device; Tx, treatment. 
Supplementary Table 8. Explorative analysis of volumetric OIRR including multiple measurements from all included studies.

\begin{tabular}{|c|c|c|c|c|c|c|c|c|c|c|c|c|}
\hline & & & \multicolumn{5}{|c|}{ FFA } & \multicolumn{5}{|c|}{ RME } \\
\hline$T x$ & Factor & Group & Arms & Trials & Mean & $95 \% \mathrm{Cl}$ & $P_{S G}$ & Arms & Trials & Mean & $95 \% \mathrm{Cl}$ & $P_{S G}$ \\
\hline Any Tx & & Overall & 17 & 3 & 15.43 & $-4.14,34.99$ & & 21 & 4 & 25.68 & $6.87,44.50$ & \\
\hline & Tooth type & $1 \mathrm{er}$ & 9 & 3 & 15.84 & $-6.98,38.66$ & 0.63 & - & & & & 0.25 \\
\hline & & $2 e r$ & 8 & 2 & 18.63 & $-55.85,93.11$ & & & & & & \\
\hline & & $3 e r$ & E & & & & & - & & & & \\
\hline & & $4 e r$ & - & & & & & 6 & 3 & 15.42 & $-20.84,51.68$ & \\
\hline & & $5 e r$ & - & & & & & 4 & 1 & ne & & \\
\hline & & $6 e r$ & - & & & & & 11 & 4 & 33.45 & $-5.23,72.12$ & \\
\hline & & $7 e r$ & 1 & & & & & F & & & & \\
\hline & & & & & & & & 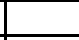 & & & & \\
\hline & $\begin{array}{l}\text { Tooth } \\
\text { group }\end{array}$ & Anterior & - & & & & & - & & & & \\
\hline & & Posterior & E & & & & & 21 & 4 & 25.68 & $6.87,44.50$ & \\
\hline & & & & & & & & & & & & \\
\hline & Jaw & Upper & & & & & & 21 & 4 & 25.68 & $6.87,44.50$ & \\
\hline & & Lower & & & & & & E & & & & \\
\hline & & & & & & & & & & & & \\
\hline & Jaw*aroup & Posterior mandible & & & & & & F & & & & \\
\hline & & Posterior maxilla & & & & & & 21 & 4 & 25.68 & $6.87,44.50$ & \\
\hline & & Anterior mandible & & & & & & - & & & & \\
\hline & & Anterior maxilla & & & & & & - & & & & \\
\hline & & & & & & & & & & & & \\
\hline Complete Tx & & Overall & 1 & 1 & $\mathrm{NE}$ & & & 10 & 3 & 27.98 & $-11.81,67.78$ & \\
\hline & & & & & & & & & & & & \\
\hline & Tooth type & $1 \mathrm{er}$ & & & & & & - & & & & 0.02 \\
\hline & & $2 e r$ & & & & & & - & & & & \\
\hline & & $3 e r$ & & & & & & - & & & & \\
\hline & & $4 e r$ & & & & & & 3 & 2 & 14.75 & $-57.69,87.19$ & \\
\hline & & $5 e r$ & & & & & & 2 & 1 & ne & & \\
\hline & & $6 e r$ & & & & & & 5 & 3 & 40.17 & $6.89,73.45$ & \\
\hline & & $7 e r$ & & & & & & & & & & \\
\hline & & & & & & & & & & & & \\
\hline & $\begin{array}{l}\text { Tooth } \\
\text { group }\end{array}$ & Anterior & & & & & & & & & & \\
\hline & & Posterior & & & & & & & & & & \\
\hline & & & & & & & & & & & & \\
\hline & Jaw & Upper & & & & & & & & & & \\
\hline & & Lower & & & & & & & & & & \\
\hline & & & & & & & & & & & & \\
\hline & Jaw*group & Posterior mandible & & & & & & & & & & \\
\hline & & Posterior maxilla & & & & & & & & & & \\
\hline & & Anterior mandible & & & & & & & & & & \\
\hline & & Anterior maxilla & & & & & & & & & & \\
\hline
\end{tabular}

* Intrusion of overerupted molars with skeletal anchorage reported by a single study and is excluded.

NE, not estimated. 